Int. J. Dev. Biol. 52: 489-501 (2008)

doi: $10.1387 / \mathrm{ijdb} .072545 \mathrm{lb}$

\title{
Crisp proteins and sperm chemotaxis: discovery in amphibians and explorations in mammals
}

\author{
LINDSEY A. BURNETT, XUEYU XIANG, ALLAN L. BIEBER and DOUGLAS E. CHANDLER* \\ Molecular and Cellular Biology Program, School of Life Sciences and the Department of Chemistry and Biochemistry, \\ Arizona State University, Tempe, AZ USA
}

\begin{abstract}
Crisp proteins appear to play multiple roles in the life history of sperm. One of these roles is to act as a sperm chemoattractant. Allurin, a $21 \mathrm{kDa}$ Crisp protein rapidly released from the egg jelly of at least two frogs, $X$. laevis and $X$. tropicalis, elicits directed motility in both homospecific and heterospecific sperm. In $X$. tropicalis, allurin is coded for by the newly documented Crisp $A$ gene. Recently, the observation that allurin can also elicit chemotaxis in mouse sperm raises the question of whether allurin-like proteins might act as sperm chemoattractants in mammals. Although an allurin gene has yet to be documented in mammals, Crisp proteins truncated post-translationally appear to exist in both the male and female reproductive tract of mammals.
\end{abstract}

KEY WORDS: fertilization, sperm motility, allurin, egg jelly, extracellular matrix

\section{Introduction}

Fertilization consists of a carefully coordinated series of events requiring sperm-egg communication at every step (Wassarman et al., 2001; Primakoff and Myles; 2002; Evans and Florman, 2002; Hoodbury and Dean, 2004). The earliest step of sperm-egg communication is chemotaxis of the sperm toward the egg in response to an egg or ovum associated factor (Eisenbach, 2007; Eisenbach and Giojalas, 2006; Kaupp et al., 2006). Since the source of the signal is typically the egg extracellular matrix, the accessory cells surrounding the egg or the egg itself, sperm need only to detect an ascending chemical gradient of the signal and follow it to its origin. To follow the gradient, the sperm must be equipped with a receptor for the chemotactic factor and an intracellular control system that modulates the flagellar movement such that the sperm is either turned toward the egg periodically (in mammals) or is changed in its pattern of swimming such that the sperm sweeps out a trajectory that brings it ever closer to the egg (as in invertebrates).

The chemotactic factors used for such communication are extremely diverse (see Table 1). Some of the earliest and best studied sperm chemoattractants are the peptides resact and speract found in the egg jelly of sea urchins (Ward et al., 1985; Shimomura et al., 1986; Dangott et al., 1989; Garbers, 1989; Garbers et al., 1994; Suzuki, 1995; Shiba et al., 2005). Sperm detection of such peptides begins with their binding to a guanylate cyclase receptor, production of an intracellular cGMP signal that in turn leads to a cascade of ionic events including opening of potassium channels, hyperpolarization of the plasma membrane, initiation of calcium waves, and activation of adenylate cyclase and cyclic AMP dependent kinase (Kaupp et al., 2003; Bohmer et al., 2005; Strunker et al., 2006; Darszon et al., 2006, 2007; Wood et al., 2005. 2007; Darszon et al., this issue). These events result in an increase in dynein heavy chain ATPase activation, a subsequent increase in flagellar beat frequency and an alteration in the pattern of flagellar dynein activity resulting in asymmetric bends in the flagellum and turning of the sperm (Cook et al., 1994; Brokaw, 1979, 1999, 2002; Shiba et al., 2005).

Sperm chemotaxis has been studied extensively in a number of marine species with external fertilization including sea urchins, starfish, ascidians, abalone, and coral (Miller, 1985; Neill and Vacquier, 2004; Nishigaki et al., 1996; Yoshida et al., 1993, 2002; Ishikawa et al., 2004; Riffell et al., 2002, 2004; Matsumoto et al., 2003; Morita etal., 2006; Shiba etal., 2006). The chemical identity of the attractants used ranges from peptides to proteins to lipids to sulfated steroids (see Table 1). Species specificity of marine sperm chemoattractants has been documented in a number of these organisms and has been found to be very high in some brittle stars and mussels while being familial in organisms such as starfish and sea cucumbers. Some level of chemotactic specificity is thought to be required in these organisms because fertilization is external; gametes from multiple species are spawned simulta-

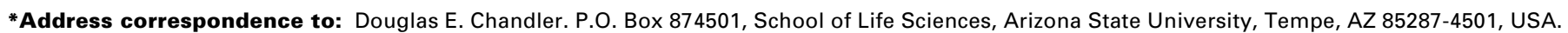
Fax: +1-480-965-6899. e-mail: d.chandler@asu.edu
}

Published online: 4 July 2008

0214-6282/2008/\$35.00

(c) UBC Press

Printed in Spain 
neously and gametes are broadly distributed by currents, and consequently, chemotaxis may play an important role in gamete recognition in these species (Miller, 1985; Babcock, 1995).

Among vertebrates, sperm chemotaxis has been studied principally in mammals. In all mammalian species studied, follicular fluid has been demonstrated to elicit sperm chemotaxis although the full spectrum of factors involved remains unclear (Ralt et al., 1991; Cohen-Dayag et al., 1995; Oliveira et al., 1999). The evidence for progesterone to be an important chemoattractant is strongest (Teves et al., 2006; Villanueva-Diaz et al., 1995). Follicular fluid contains progesterone, the egg and surrounding cumulus cells have been shown to produce progesterone, and sperm from a number of mammalian species including humans chemotax toward relatively low concentrations of progesterone in vitro (Sun et al., 2005; Teves et al., 2006). Since progesterone also initiates hyperactivated sperm motility and triggers the acrosome reaction at higher concentrations in vitro, this steroid clearly has multiple important roles in mammalian sperm physiology (Eisenbach and Giojalas, 2006; Eisenbach et al., this issue). In contrast to marine invertebrates, heterospecific chemotaxis of mammalian sperm to follicular fluid has been reported for a relatively diverse group of mammals, implying that mammals likely do not rely on chemotaxis as a mechanism to prevent interspecies fertilization or to mediate species-specific gamete recognition (Sun et al., 2003).

In vitrostudies have indicated that odorants such as bourgeonal and lyral also have sperm chemoattractant activity but the biological role of these agents in vivo remains unclear as these compounds have yet to be isolated from follicular fluid or egg extracellular matrix components. Bourgeonal and lyral bind to G-protein coupled odorant receptors designated as hOR17-4 and mOR23 respectively. In humans, it has been demonstrated that hOR17-
4 activation is coupled to a cAMP-mediated-signaling cascade; ultimately calcium influx occurs and flagellar beating is modified resulting in directed motility (Spehr et al., 2003, 2006; Fukuda et al., 2004; Spehr et al., this issue). Calcium influx also occurs in mouse sperm in response to mOR23 activation by the small aromatic aldehyde lyral and this too results in modification of flagellar beating and directed movement.

A relatively large void exists in our knowledge of sperm chemotaxis mechanisms between the exquisite biochemical and cellular studies in marine invertebrates and the critical physiological studies of chemotaxis in mammals. More recently knowledge of sperm chemotactic mechanisms has been augmented by studies in fish and amphibians. Motility activation and chemotaxis of sperm in fish is best represented by work on the Pacific herring. Sperm motility in the herring can be initiated by both diffusible peptides (herring sperm activating factors; HSAPs) and by a chorion protein (sperm motility initiation factor, SMIF) that is located close to the micropyle which the sperm must enter in order to reach the egg surface (Oda et al., 1998; Vines et al., 2002). HSAPs are considered to initiate sperm motility and chemotaxis while SMIF triggers the sperm to swim in circles thereby increasing the probability that it will enter the micropyle.

In amphibians, Xenopus laevis and Xenopus tropicalis have now taken a commanding lead in the study of sperm chemotaxis in lower vertebrates. Studies for over 40 years have indicated that the egg jelly of amphibians contains factors important for fertilization success (Katagiri, 1987). Once jelly is removed from a frog egg, fertilization plummets from about $95 \%$ to $10 \%$; if jelly is added back in the form of jelly glycoproteins solubilized by reducing agents, fertilization is fully restored (Olson and Chandler, 1999). Although the full range of biological activities in jelly is still unknown, it quickly became clear that one such activity was that

TABLE 1

\section{SPERM CHEMOATTRACTANTS ARE CHEMICALLY DIVERSE}

\begin{tabular}{|c|c|c|c|c|}
\hline Species & Agent & Type & Sperm responses & References \\
\hline $\begin{array}{l}\text { Sea Urchin } \\
\text { A. punctulata }\end{array}$ & Resact & Peptide, 14 residues & $\begin{array}{l}\text { Chemotaxis; cGMP signals, flagellar bending, } \\
\text { initiates circular paths }\end{array}$ & $\begin{array}{l}\text { Ward et al., 1985;Garbers, 1989; Bohmer } \\
\text { et al., } 2005\end{array}$ \\
\hline $\begin{array}{l}\text { Sea Urchin } \\
\text { S. purpuratus }\end{array}$ & Speract & Peptide, 10 residues & $\begin{array}{l}\text { Chemokinesis; chemotaxis, calcium waves, } \\
\text { flagellar bending }\end{array}$ & Shiba et al., 2005; Wood et al., 2005 \\
\hline Starfish & StarTrak & Protein, $13 \mathrm{kD}$ & Chemotaxis & Miller and Vogt, 1996 \\
\hline Starfish & Asterosaps & Peptides with steroidal co-agent & $\begin{array}{l}\text { Chemokinesis; } \\
\text { Chemotaxis (?) }\end{array}$ & $\begin{array}{l}\text { Nishigaki et al., 1996; Matsumoto et al., } \\
2003\end{array}$ \\
\hline Coral & Dodeca-2,4-diynol (among others) & Low molecular weight lipid & Chemotaxis & Babcock, 1995; Morita et al., 2006 \\
\hline Brown Algae & Finaverrene (among others) & Unsaturated $\mathrm{C}_{11}$ hydrocarbons & Chemotaxis; mating synchrony & Boland et al., 1995; Muller et al., 1982 \\
\hline Ascidians & Sulfated Steroids & Sulfated Steroid & Initiation of circular swimming paths & Yoshida et al., 2002 \\
\hline Abalone & L-Tryptophan & Amino Acid & Chemotaxis & Riffel et al., 2002, 2004 \\
\hline Jellyfish & Egg/ovarian extracts & Unknown & Chemotaxis; activation of motility & Miller et al., 1997 \\
\hline Cuttlefish & SepSAP & Amidated hexapeptide & Chemotaxis & Zatylny et al., 2002 \\
\hline $\begin{array}{l}\text { Fish } \\
\text { Herring }\end{array}$ & HSAPS & Peptides & Chemotaxis & Oda et al., 1998 \\
\hline $\begin{array}{l}\text { Frog } \\
X . \text { laevis } \\
X . \text { tropicalis }\end{array}$ & Allurin & Protein, $21 \mathrm{kDa}$ & Chemotaxis & Al-Anzi et al., 1998; Olson et al., 2001 \\
\hline $\begin{array}{l}\text { Mouse } \\
\text { M. musculus }\end{array}$ & Progesterone, follicular fluid & $\begin{array}{l}\text { Steroid, } \\
\text { unknown agent }\end{array}$ & Chemotaxis, calcium waves & Giojalas et al., 1998 \\
\hline $\begin{array}{l}\text { Human } \\
\text { H. sapiens }\end{array}$ & Follicular fluid & unknown agent & Chemotaxis & Ralt et al., 1991; Olivera et al., 1999 \\
\hline $\begin{array}{l}\text { Human } \\
\text { H. sapiens }\end{array}$ & Progesterone & Steroid & $\begin{array}{l}\text { Chemotaxis; hyperactivated motility; calcium } \\
\text { signaling; acrosome reaction }\end{array}$ & $\begin{array}{l}\text { Villanueva-Diaz, 1995; Teves et al., 2006; } \\
\text { Kirchman-Brown et al., } 2002 .\end{array}$ \\
\hline $\begin{array}{l}\text { Human } \\
\text { H. sapiens }\end{array}$ & Bourgeonal & Aromatic aldehyde & Chemotaxis; calcium waves, cGMP signals & Spehr et al., 2003, 2006 \\
\hline
\end{tabular}


of a sperm chemoattractant, allurin (Al-Anzi and Chandler, 1998). As expected of a sperm chemoattractant, allurin was found to be among the proteins that rapidly diffuse out of the jelly and therefore a rich source of the protein was «egg water, " medium conditioned by incubation with freshly spawned eggs for periods as short as 5 minutes (Olson et al., 2001; Xiang et al., 2005).

Purification, sequencing and molecular cloning of allurin mRNA provided evidence that this protein belongs to the CRISP (Cysteine-RIch Secretory Protein) family, members of which were already known to be mammalian sperm binding proteins (Olson et al., 2001). A rapidly expanding subject of research, Crisp family proteins are now proposed to be involved in numerous steps of sperm maturation and sperm-egg interaction as illustrated in Fig. 1. In the male reproductive tract Crisp 2 is produced by developing spermatids and is thought to mediate Sertoli cell-spermatocyte adhesion during spermatogenesis (Maeda et al., 1998). In addition, Crisp 2 is packaged into the acrosomal granule (Hardy et al., 1988; Foster and Gerton, 1996). During later stages of sperm maturation in the epididymis Crisp 1, Crisp 4, and Crisp 3 (in some species) are produced and interact with the sperm surface (Roberts et al., 2006, 2007). After ejaculation and entry into the female reproductive tract, sperm shed loosely bound Crisp 1 and acquire the ability to capacitate by the time they enter the ampulla of the oviduct (Rochwerger and Cuasnicu, 1992a; Roberts etal., 2003). In Xenopus, sperm are guided to the egg by a gradient of the Crisp family protein allurin. Recent data leads us to propose that a similar mechanism may exist in mammals; that as capacitated spermatozoa swim up the oviduct in search of a fertilizable egg, Crisp proteins not unlike allurin (along with other factors such as progesterone) elicit sperm chemoattraction and direct motility of the sperm toward the egg. After arrival at the egg, sperm must next bind to the zona pellucida, penetrate it, bind and fuse with the egg plasma membrane. Crisp 1 has been shown to regulate sperm capacitation, and this protein has also been implicated in sperm-zona pellucida binding and sperm-egg fusion (Cohen et al., 2007; Cuasnicu et al., this issue). At the zona pellucida, Crisp 1 , present on the dorsal head of sperm, modulates sperm-zona binding and migrates to the equatorial segment during the acrosome reaction. After migration, sperm-bound Crisp 1 is proposed to be involved in sperm-egg plasma membrane fusion through binding to specific Crisp protein receptors on the egg surface (Cuasnicu et al., this issue). Crisp 2 has also been implicated in sperm-egg plasma membrane fusion events since it is also able to bind to eggs at the same sites as Crisp 1 and is present in the acrosomal granule of sperm (Busso et al., 2007b).

\section{The CRISP Family}

The Crisp protein family is the vertebrate branch of the CRISP/Antigen 5/PR-1 (CAP) superfamily which includes proteins from species as diverse as prokaryotes, plants, fungi, insects, reptiles, avians, amphibians, and mammals (Kratzschmar et al., 1996). As shown in the phylogenetic tree of Fig. 2, the CRISP families radiated from CAP ancestral genes that gave rise not only to pathogenesis-related proteins found in numerous plant families (the PR proteins, not shown) and venom antigens in insects such as wasps and bees but also to the complete variety of Crisps found in snake venoms, amphibian reproductive tissues, and reproductive organs of all commonly studied mammals (Gibbs and O'Bryan, 2007). Studies of plant and venom CAP proteins have contributed significantly to knowledge of Crisp structure and function; notably, the complete tertiary structure of the tomato pathogenesis-related protein P14a has been determined by NMR (Fernandez et al., 1997), the structure of wasp and hookworm venom antigen proteins have been determined by $\mathrm{x}$ ray crystallography (Henriksen et al., 2001; Asojo et al., 2005), and three snake venom Crisp proteins have had their $\mathrm{x}$-ray crystal structures solved as well (Fig. 2; Wang et al., 2004; Wang et al., 2005; Guo et al., 2005; Shikamoto et al., 2005).

All members of the CAP/CRISP family share a homologous Nterminal CAP domain of about 160 amino acids which is also referred to as the pathogenesis-related or PR domain since its amino acid sequence is homologous to and its structure (where determined) is similar to that of pathogenesis-related proteins in plants (see Fig. 3). This domain contains 6 conserved cysteine residues that form 3 disulfide bonds in most family members. The PR domain is linked to the cysteine-rich domain (CRD) found only in the CRISP family. The CRD domain itself is divided into a 26amino-acid hinge region that contains 4 conserved cysteines involved in 2 disulfide bonds and the ion channel regulatory (ICR) region consisting of approximately 40 amino acids including 6 conserved cysteine residues that also are disulfide bonded.

Conservation of the CRD domain is less widespread than that of the PR domain. Some CAP/CRISP family members have modified C-terminal domains that do not resemble ICR domains, for example, the wasp venom antigen (Henriksen et al., 2001). Alternatively, other CRISP family members such as the allurins and the mammalian GliPR proteins (not shown, Szyperski et al., 1998) have a hinge region but lack the ICR region. One member, a short splice variant of human Crisp 1 completely lacks both the hinge and ICR regions (Hayashi et al., 1996; Kirchhoff, 1998). Finally, all three domains have shown up in a set of larger Crisp proteins - the proteins in the LD1 and LD2 families - but interspersed with non-Crisp sequences to produce proteins of about 500 residues. The LD $1 / 2$ family also contains a LCCL domain, function unknown, for which the family is named (based on its presence in Limulusfactor C) (Clark et al., 2003). Like other Crisp

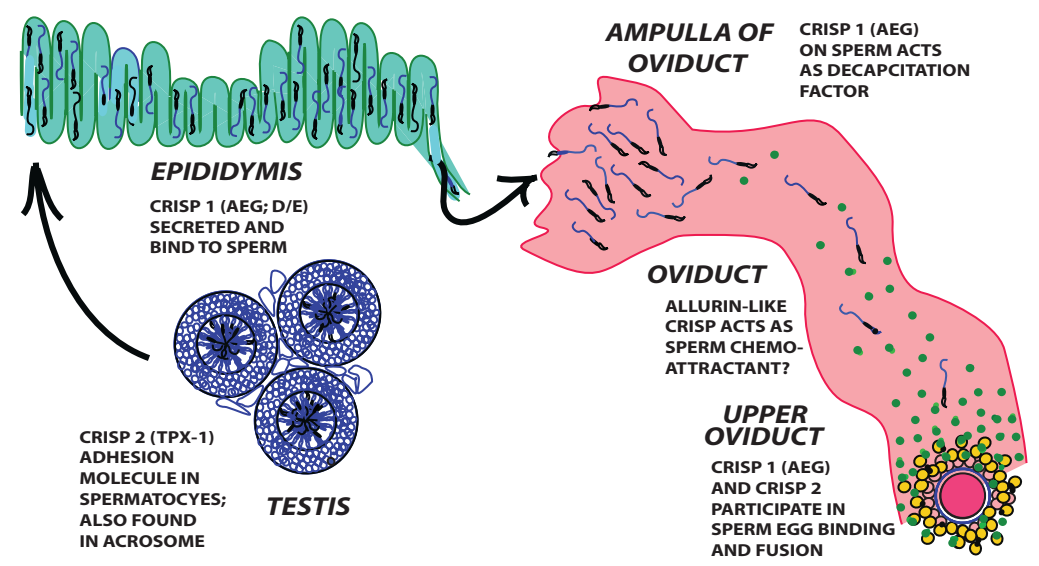

Fig. 1. Diagram of proposed Crisp protein functions in the mammalian reproductive tract. 
proteins the Crisp LD $1 / 2$ family is observed in both lower vertebrates such as frogs as well as mammals (see Figs. 2 and 3 ).

Although the basic structural relationships between the PR, Antigen and CRISP subfamilies are clear, the biological functions of each of the domains involved remain unclear. The function of the CAP/PR domain in both pathogenesis-related plant proteins and in insect venom antigens is completely unknown. In contrast, there is strong evidence that the CAP/PR domain of mammalian Crisps is a sperm binding domain that plays an important role in sperm maturation, capacitation and sperm-egg binding and fusion. For this reason databases for conserved protein domains (e.g. CDD at $\mathrm{NCBI}$ ) recognize the CAP/PR domain as a «sperm coating protein» (SCP) domain with two highly conserved «signature " sequences that in mouse Crisp 1 are found at residues 120130 and residues 148-159. As an example, studies with the mammalian sperm binding protein Crisp 1 in rat, mouse and human demonstrate that incubation of this protein with zona-free eggs can prevent sperm-egg fusion (Rochwerger et al., 1992b; Cohen et al., 1996, 2000a, 2001). The activities of overlapping

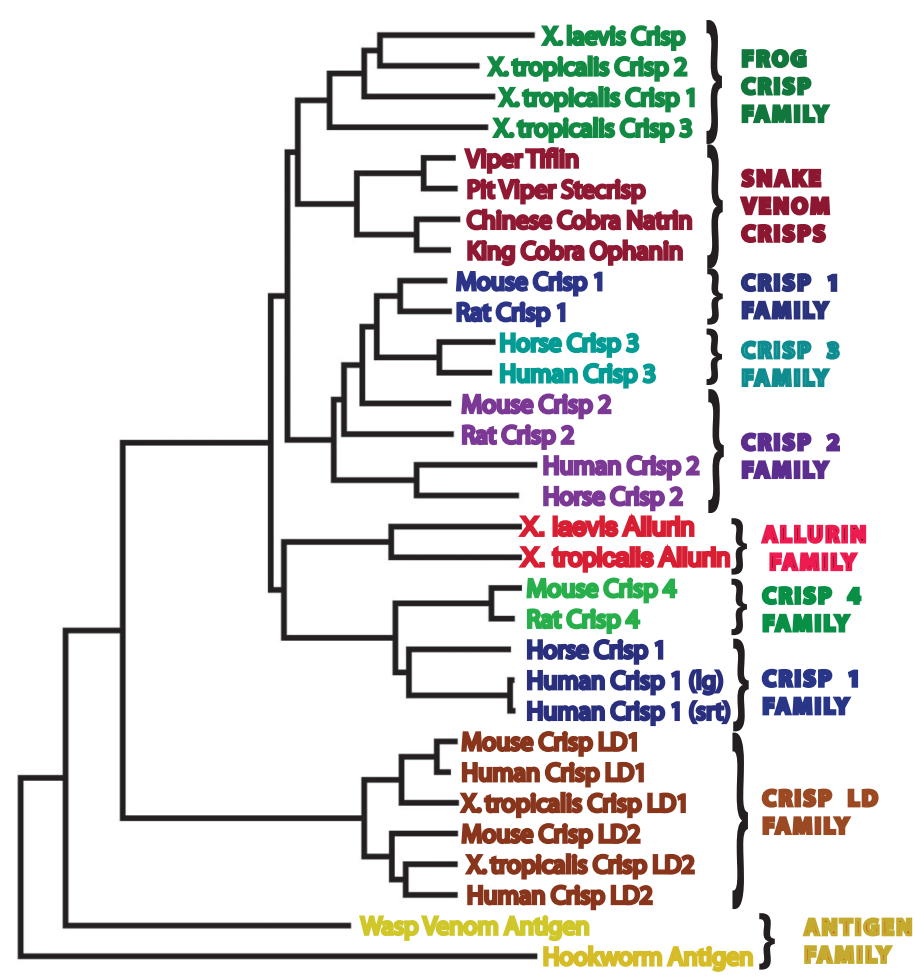

Fig. 2. Phylogenetic relationships between Crisp proteins. The tree was constructed using amino acid sequences, default parameters for Clustal W alignment and nearest-neighbor joining methods in MEGA 4 (Tamura et al., 2007). The GenBank Identification numbers for the sequences used (from top to bottom) are: 147901846, 56118479, $77621326,45361474,21305552,60593434,32492058,28972960$, $31981913,12408313,126352541,5174674,6678422,13676848$, 4507670, 126352425, 15987512 (X. laevis allurin), 73788810, 88595370, $86476049,126352648,25121981,25121983,123173745,52694670$, scaffold_260:1567801-1600106 (X. tropicalis Crisp LD1, putative), 60592999, 73853835, 142374443, 162550, 3396069. synthetic peptides indicate that the region of Crisp 1 responsible for this action is the second amino acid signature sequence (148159) in the CAP/PR domain (Ellerman et al., 2006). However, the functional role of the CAP domain in mammalian Crisp proteins found in non-reproductive tissues remains unknown.

Studies in venom proteins have provided a more general model for CRD domain functionality. The ICR domain of the CRD structurally resembles ion channel regulatory proteins that have been identified in the sea anemone, namely Bgk and Shk (Casteneda et al., 1995; Cotton et al., 1997). Ion channel regulatory activity of Crisp proteins has been examined most thoroughly for helothermine, a Crisp family venom protein from the Mexican beaded lizard. Helothermine blocks activity of a number of channels including voltage-gated $\mathrm{Ca}^{2+}$ and $\mathrm{K}^{+}$channels as well as ryanodine receptor $\mathrm{Ca}^{2+}$ channels (Nobile et al., 1994, 1996; Morrissette etal., 1995). This activity is not unique to helothermine; other Crisps including, natrin, pseudecin and pseudechetoxin also have $\mathrm{Ca}^{2+}$ and $\mathrm{K}^{+}$channel blocking activity (Wang et al., 2005; Brown et al., 1999; Yamazaki, 2002). Other Crisps have been shown to prevent contraction of smooth muscle suggesting that they might have ion channel inhibitory abilities as well.

Further studies of the CRD domain have been carried out in mammalian Tpx-1/Crisp 2. Synthetic peptides representing the CRD domain of Crisp 2 alone were shown to be capable of blocking ryanodine receptors in smooth muscle in vitro and by NMR spectroscopy were shown to have a tertiary structure very similar to the CRD domain of snake venom Crisps (Gibbs et al., 2006). These data suggest a common mechanism of Crisp family members: ion channel regulation, which could affect numerous processes in different species and tissues.

In mammals a number of Crisp family proteins have been identified and characterized, primarily in the male reproductive tract. Six Crisp genes have been identified in mouse of which four are well studied and considered to be paralogs: Crisp 1, Crisp 2, Crisp 3 and Crisp 4. Likewise, three paralogous genes have been identified in rat (Crisp 1, Crisp 2, and Crisp 4) and three in human (Crisp 1, Crisp 2, and Crisp 3) (see Fig. 2). In most cases these Crisp family proteins are expressed in the male reproductive tract in an androgen-dependent manner and are thought to play a role in sperm maturation and sperm-egg interactions (Dacheux et al., 2006; Udby et al., 2005; Jalkanen et al., 2005; Eberspraecher et al., 1995; Schwidetzky et al., 1995; Kratzschmar et al., 1996).

As summarized in Table 2, the mammalian Crisp proteins have been implicated in a number of fertilization events. Crisp 1, wellstudied in rodents and also known as protein DE and acidic epididymal glycoprotein (AEG), is secreted in the epididymis and binds to the sperm surface during epididymal transit (Rochwerger and Cuasnicu, 1992a; Roberts et al., 2001, 2002; Tubbs et al., 2002). Crisp 1/AEG/Protein DE is present in two forms that are thought to be identical in amino acid sequence but immunologically distinguishable (Roberts et al., 2002, 2006). The first form, protein $\mathrm{D}$, is the major species of Crisp 1 present in epididymal fluid ( $>95 \%$ of total) and the second form, protein E, is thought to differ from $D$ by the addition of an O-linked oligosaccharide having at least one $\mathrm{N}$-acetyl-glucosamine (Roberts et al., 2006). Proteins $\mathrm{D}$ and $\mathrm{E}$ exhibit differential expression; Protein $\mathrm{D}$ is synthesized more proximally in the epididymis than protein $\mathrm{E}$ (Roberts et al., 2002). These proteins also exhibit different sperm-binding abilities. Protein $\mathrm{D}$ appears to bind to the sperm surface in a transient 
TABLE 2

\section{REPRODUCTIVE FUNCTIONS OF CRISP FAMILY PROTEINS IN MAMMALS}

\begin{tabular}{|c|c|c|c|c|}
\hline Process & Proteins Involved & Location of Action & Specific Functions & References \\
\hline Gametogenesis & Crisp 2 & Testes & Sertoli cell adhesion; acrosome biogenesis & $\begin{array}{l}\text { O'Bryan et al., 2001; Maeda et al., 1998; } \\
\text { Hardy et al., } 1988\end{array}$ \\
\hline Epididymal Maturation & $\begin{array}{l}\text { Crisp } 1 \\
\text { Crisp } 4 \\
\text { Crisp } 3\end{array}$ & Epididymis & $\begin{array}{l}\text { Coat sperm surface (Crisp } 4 \text { in proximal epididymis, Crisp } 1 \text { in distal } \\
\text { epididymis); Seminal plasma components (Crisp 1, } 4 \text { and } 3 \\
\text { (humans and horse)) }\end{array}$ & $\begin{array}{l}\text { Rochwerger and Cuasnicu, 1992; Roberts } \\
\text { et al., 2001, 2002; Schambony et al., } \\
\text { 1998a,b }\end{array}$ \\
\hline Capacitation & Crisp 1 & Oviduct Ampulla & $\begin{array}{l}\text { Decapacitation factor; unbinding/ migration at sperm surface to } \\
\text { allow capacitation to proceed }\end{array}$ & $\begin{array}{l}\text { Roberts et al., 2003, 2007; Rochwerger } \\
\text { and Cuasnicu, } 1992\end{array}$ \\
\hline Chemoattraction & $\begin{array}{l}\text { Truncated Crisp 1? } \\
\text { Allurin? }\end{array}$ & Oviduct & Sperm chemoattraction? & Proposed here \\
\hline Zona-Pellucida Interaction & Crisp 1 & Zona Pellucida & Zona penetration & Busso et al., 2007 \\
\hline Gamete Fusion & $\begin{array}{l}\text { Crisp } 1 \\
\text { Crisp } 2\end{array}$ & Egg plasma membrane & $\begin{array}{l}\text { Crisp } 1 \text { (equatorial region/ fusogenic region) } \\
\text { Crisp } 2 \text { (acrosomal matrix) }\end{array}$ & $\begin{array}{l}\text { Cuasnicu, this issue; Ellerman et al., 2006; } \\
\text { Busso et al., 2005, 2007; Cohen et al., } \\
\text { 2001; Da Ros et al., } 2007\end{array}$ \\
\hline
\end{tabular}

and reversible manner whereas Protein $\mathrm{E}$ binds essentially irreversibly (Roberts et al., 2007). In addition, protein D has been shown to bind principally to the head of rat sperm; in contrast, protein $\mathrm{E}$ has been shown to bind almost exclusively to the tail by immunocytochemistry with protein $\mathrm{E}$ specific antibodies.

Both Protein D and $E$ are thought to be present in full-length and proteolytically processed forms; proteolytic processing is proposed to occur after secretion resulting in a heterogeneous protein D/E population composed of full-length, high molecular weight (about $32 \mathrm{kDa}$ ) forms as well as lower molecular weight forms. The lowest molecular weight form of Protein $E$ (approximately $22 \mathrm{kDa}$ ) is most strongly associated with the sperm surface. Based on the loss of cross-reactivity with an antibody that recognizes part of the CRD domain, this form of Crisp 1 is presumed to undergo a C-terminal cleavage event resulting in a truncated form of this protein lacking the CRD domain (Roberts et al., 2007).

After ejaculation, in the female reproductive tract, Crisp 1 is shed from the surface of sperm concomitant with capacitation. Indeed, Crisp 1 in the epididymis is thought to prevent sperm capacitation presumably by an unknown ion channel regulatory mechanism; incubation of sperm with exogenous full-length Crisp 1 results in inhibition of the tyrosine phosphorylation usually seen during capacitation and the ability of the sperm to undergo progesteroneinduced acrosome reaction (Roberts et al., 2003). This inhibition or "decapacitation" can be rescued by removing the sperm from exogenous Crisp 1-containing media; the degree of sperm recovery is inversely correlated with the amount of Protein D remaining bound to the sperm surface. Thus, as ambient Crisp 1 levels decrease in the female tract, loosely bound Crisp 1 (presumably mostly protein D) dissociates from the sperm surface thereby allowing the sperm to capacitate (Roberts et al., 2007).

Dissociation of protein $D$ from the sperm surface to permit capacitation appears to be partial; immunocytochemistry demonstrates that a por- tion of Crisp 1 remains bound to the dorsal region of the sperm head after capacitation (Rochwerger and Cuasnicu, 1992a). Subsequently, during the acrosome reaction, this Crisp $1 \mathrm{mi}-$ grates to the equatorial region, a location considered vital for subsequent sperm-egg fusion (Da Ros et al., 2004). Crisp 1 migration is bicarbonate dependent (like capacitation) and some sperm show evidence of early migration even during capacitation (Rochwerger and Cuasnicu, 1992a; Da Ros et al., 2004). Thus, Crisp 1, before migration, is in position to influence sperm-zona pellucida binding while after migration is positioned to play a role in sperm-egg plasma membrane binding (Cohen et al., 2007)

Indeed, recent studies indicate that purified Crisp 1 can bind to both the zona pellucida and the egg plasma membrane of rodent eggs. In fact, incubation of zona-intact eggs with either anti-Crisp 1 antibodies or exogenous Crisp 1 results in a decrease in number of sperm bound to the zona pellucida (Busso et al., 2007a). In addition to its possible role in sperm-zona interactions, Crisp 1 has been directly implicated in regulation of sperm-egg fusion at the plasma membrane. As discussed previously, Crisp 1 can bind to the egg plasma membrane of zona-free eggs through a conserved signature region and regulate or mediate sperm-egg fusion (Ellerman et al., 2006; Cohen et al., 1996, 2000a, 2007; Da Ros et al., 2006, 2007a). Zona-free eggs incubated with exog-

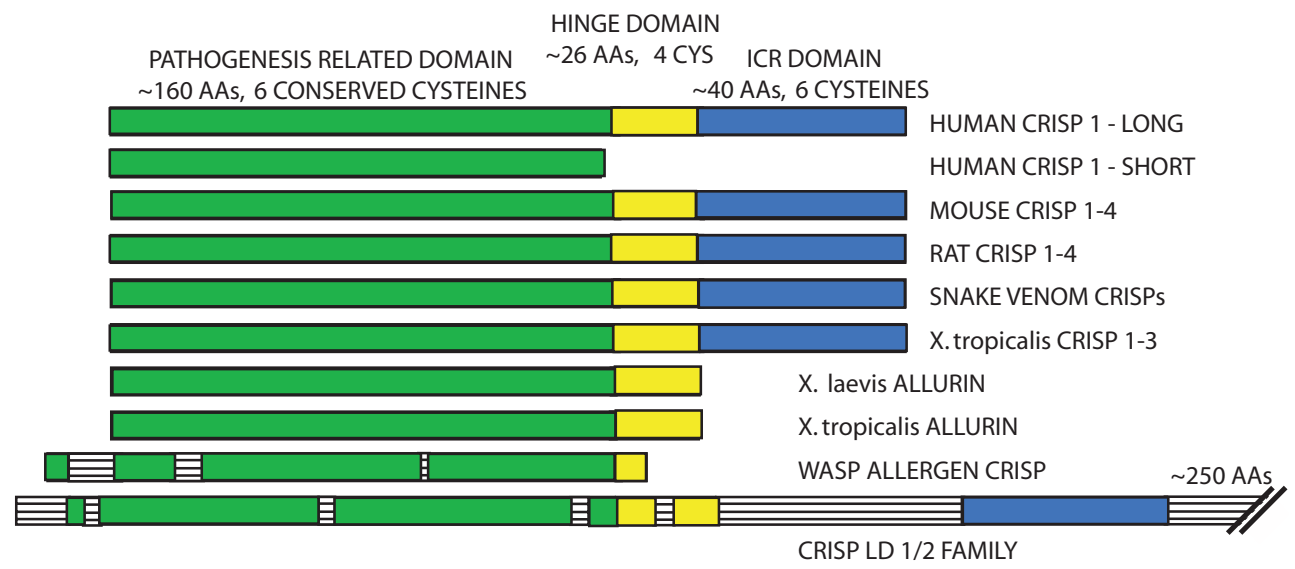

Fig. 3. Domain organization of selected Crisp proteins. Amino acid sequences characteristic of the pathogenesis-related (PR), hinge and ion channel regulatory (ICR) domains are represented by green, yellow and blue bars respectively. Regions of non-Crisp amino acid sequences are indicated by hatched bars. Bar lengths are not strictly to scale. 
enous purified Crisp 1 or a synthetic peptide representing the egg binding domain of the protein results in a decreased number of gamete fusion events without decrease in the number of sperm binding to the egg plasma membrane (Da Ros et al., 2006). These data suggest that some form of Crisp 1 may be involved in events leading to sperm-egg fusion but that these events must come after initial sperm-egg binding (Cohen etal., 2007; Da Ros etal., 2006). Parallel studies have shown that incubation of sperm with Crisp 1 antibodies prevents fertilization and that an immunological approach may have uses in contraception (Ellerman et al., 1998, 2007). A detailed account of these studies may be found in the article by Cuasnicu et al., this issue.

Although other Crisp proteins play a role in sperm physiology their roles in sperm-egg communication are not as well defined. Crisp 2 has been shown to bind to the mouse egg plasma membrane and by competition studies is thought to bind the same complementary sites on the egg's surface as Crisp 1. Crisp 2 is presumed to bind to the egg via the same signature sequence as does Crisp 1 since this sequence in Crisp 2 differs from that in Crisp 1 by only two amino acids (Busso et al., 2005, 2007b). Crisp 2 is not found on the surface of mature sperm, but is present intraacrosomally (Hardy etal., 1988; Foster and Gerton, 1996; O'Bryan et al., 2001), suggesting that its exposure during the acrosome reaction may position it for involvement in sperm-egg fusion events (Busso et al., 2005). Crisp 2 is also found in the testes during spermatogenesis; it is produced by developing spermatids and associates with the sperm plasma membrane to mediate sperm adhesion to Sertoli cells (Maeda et al., 1998). As mentioned previously, the CRD domain of this Crisp family member has been shown to block ryanodine receptors in vitro suggesting a possible biochemical mechanism for the biological roles of Crisp 2 (Gibbs et al., 2006).

Crisp 3 has a wider tissue distribution and has not been found in the male reproductive tract of mouse; however, the equine Crisp 3 is a major protein component of horse seminal plasma (Topfer-Peterson et al., 2005). In horse, this protein is associated with the sperm surface and is correlated with fertility in stallions (Schambony et al., 1998a,b; Hamann et al., 2007). In addition, there are two molecular weight forms ( 29 and $31 \mathrm{kDa}$ ) of Crisp 3 found in human secretory epithelia (epididymal and prostatic) suggesting a possible role for this protein in reproductive function (Udby et al., 2005; Bjartell et al., 2006). In addition, Crisp 3 is also found in other tissues including neutrophils and exocrine secretions and is hypothesized to play a role in innate immunity (Haendler et al., 1993; Udby et al., 2002a,b).

Crisp 4 is expressed in multiple regions of the epididymis and has been shown to interact with sperm; however, the role of this protein in sperm function/maturation has yet to be elucidated (Jalkanen et al., 2005). Sperm in mouse and rat are exposed to Crisp 4 in the epididymis prior to exposure to Crisp 1 based on differential expression patterns of these genes. The rat and mouse Crisp 4 genes are orthologous to each other as well as orthologs of human Crisp 1 (Nolan et al., 2006). Further studies of Crisp 1 and Crisp 4 will be necessary to determine the functional relationships of these gene products.

In non-mammalian vertebrates, additional Crisps have been identified and implicated in reproductive and developmental functions. X-Crisp is a full-length Crisp family protein that is involved in degradation of the vitelline envelope resulting in hatching in
Xenopus laevis embryos (Schambony et al., 2003). The CRD domain of this protein is required for its functionality. In contrast, allurin, also identified in $X$. laevis, lacks all but four residues of the ICR portion of the CRD domain. As indicated previously, allurin is homologous to mammalian sperm binding Crisps and elicits chemotaxis in X. laevis sperm (Olson et al., 2001). More recently $X t$ allurin, the ortholog of allurin in $X$. tropicalis has been identified (Burnett et al., 2008). This protein also lacks an ICR domain, but can elicit chemotaxis in $X$. tropicalis sperm indicating that this activity must be restricted to the PR domain or hinge region of this protein. Intriguingly, sperm chemotaxis represents another functional role of Crisp family proteins in sperm maturation and spermegg interactions suggesting that sperm may be shepherded and guided by Crisp family proteins through many functional stages required to accomplish fertilization (summarized in Fig. 1).

\section{Amphibian crisps and chemoattraction}

In 2001, we purified and sequenced allurin from $X$. laevis egg jelly. Interestingly, this $21 \mathrm{kD}$ chemoattractant protein was also the first Crisp family member identified as being produced in the female reproductive tract. Allurin is dissimilar to most other known chemoattractants in that it is a protein of substantial size rather than a small molecular weight compound, but its homology to mammalian sperm binding proteins has made it an obvious target for further study.

Subsequently, we used DNA probe hybridization, RT-PCR amplification and immunocytochemistry to determine the site of allurin expression and the means by which this protein is applied to eggs as they pass down the frog oviduct (Xiang et al., 2004). Dot and western blots showed that the oviduct is the only organ to express allurin and that both allurin mRNA levels and protein levels rise substantially ( 3 and 7 fold, respectively) over a 12 hour period after human chorionic gonadotropin (hCG) priming of the frog. Most vertebrates ovulate in response to luteinizing hormonelike hormones such as hCG but frogs, in addition, increase production of both egg jelly and allurin in the oviduct. Thus, allurin also represents the first Crisp family member known to be expressed in response to hormonal stimulation in females. In the male, CRISP family members show androgen-dependent expression and in some cases androgen response elements (AREs) have been identified in CRISP gene regulatory loci. This suggests common themes in vertebrate Crisp proteins of amino acid sequence homology, function (sperm-binding), and hormoneinduced expression.

Immunocytochemistry showed that allurin secretion and application to the egg does not coincide with the application of other jelly components (Xiang et al., 2004). The luminal surface of the frog oviduct exhibits a pattern of protrusions which when seen in section consists of a series of cellular arches that cover deeper tubular glands (see Fig. 4A). At higher magnification, one can see that the cells making up the tubular glands are filled with large, basophilic granules containing high molecular weight jelly glycoconjugates (Fig. 4B). The arches themselves are covered with epithelial cells whose dense array of cilia aide propulsion of the eggs, single file, down the oviduct from ovary to uterus, a journey that takes about 3 to 4 hours. In electron micrographs, these cilia are seen to have the usual $9+2$ arrangement of microtubules and are well anchored by basal bodies in the 

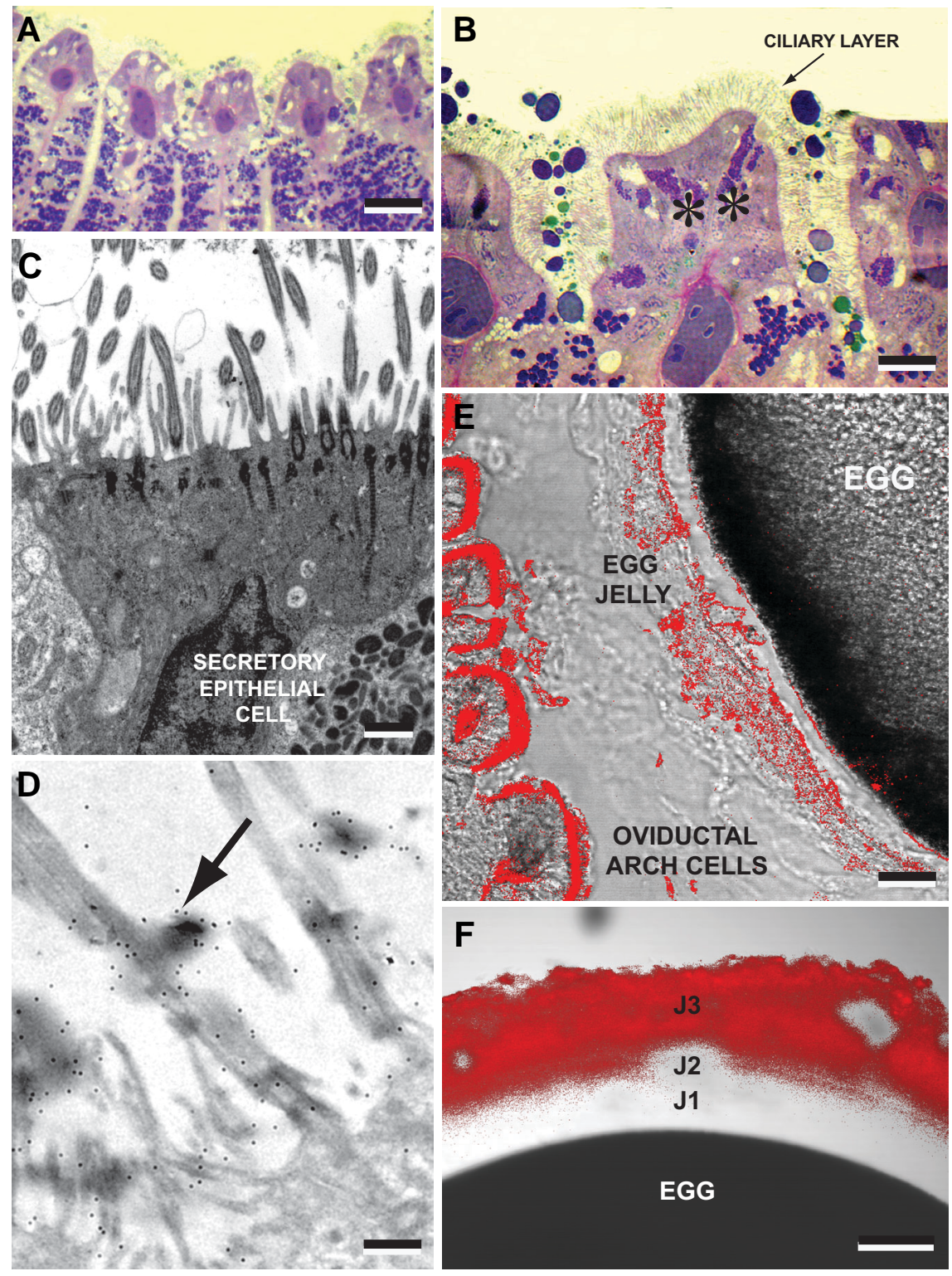

Fig. 4. Secretion of allurin in the frog oviduct and its application to the egg. (A) The X. laevis oviduct consists of tubular jelly secreting glands capped by arches of epithelial cells that face the oviduct lumen. Below the arches, cells that synthesize and secrete jelly glycoconjugates are filled with large, strongly basophilic granules. The cells of each tubular gland fan out from a central duct that empties into the lumen at the crevices between the epithelial arches. Bar, $25 \mu \mathrm{m}$. (B) Each arch contains at its center a capillary loop filled with blood cells. Covering the capillary is a single layer of ciliated epithelial cells and interspersed among these cells are occasional secretory cells that have clusters of lightly stained granules (asterisks). These are thought to be the allurin producing cells. Bar, $10 \mu \mathrm{m}$. From Chandler and Roberson, 2008 with copyright permission from Jones and Bartlett Publishers (C) Electron micrograph of cilia emerging at the apical plasma membrane of arch epithelial cells. Bar, $1 \mu \mathrm{m}$. (D) Immunocytochemical localization of allurin at the ultrastructural level. Arrows point to colloidal gold beads marking the presence of allurin on the extracellular surface of the cilia. Bar, $0.4 \mu \mathrm{m}$. (E) Immunocytochemical localization of allurin as it is applied to an egg passing down the oviduct. The secondary antibody signal (red) is superimposed on a transmitted light image of the egg and oviductal epithelium. Heavy deposits of allurin on the ciliary border are mixed with jelly and "brushed" onto the egg. Bar, $10 \mu \mathrm{m}$. (F) In the freshly spawned egg, allurin has become concentrated in the outmost (J3) jelly layer poised to be released into the medium. Bar, $100 \mu \mathrm{m}$. From Xiang et al., Dev. Biol. 275:343-355 (2004) with copyright permission from Elsevier Science. epithelial cells (Fig. 4C).

Localization of anti-allurin antibodies in the oviduct (red signal, Fig. 4E) shows that massive amounts of this protein are present in the ciliary layer of the arch cells and that this protein is "painted" onto the egg as it passes. Immunocytochemistry at the electron microscopy level confirms that allurin is present on the extracellular surfaces of these microvilli (arrow, Fig. 4D). These cilia therefore, might literally be considered a "brush" border. In contrast, the deeper simple tubular glands of the oviduct that produce jelly show no staining for allurin nor is there allurin present in the secretory ducts associated with these glands. Instead, allurin appears to be released from secretory cells in oviductal epithelium that are nestled between the more numerous ciliated cells (asterisks, Fig. 4B). Once the ciliary "brush" is loaded by these cells, allurin and high molecular weight jelly glycoconjugates from the tubular glands are mixed as they are applied to the passing egg. The bulk of the allurin is applied to the egg with the innermost jelly layer (J1) in the upper portion of the oviduct. Following application, allurin diffuses from $\mathrm{J} 1$ and ultimately to J3, the outermost layer, during subsequent jelly additions (see Fig. 4F). This change in localization readies allurin for rapid diffusion from the egg jelly upon spawning (Xiang et al., 2005).

Although allurin is a relatively large chemoattractant it is effectively and rapidly released into the medium resulting in timely formation of an allurin gradient. Western blotting confirmed the appearance of allurin in the medium within 1.5 minutes and nearly half of the allurin present in the jelly layers is released within 5 minutes after spawning. Computer modeling showed that both diffusion and medium mixing at the jelly surface during spawning are both needed to account for this rapid release (see Fig. 5A). Release is likely accomplished by swelling and ion exchange of the medium with J3 components. J2, a compact and less permeable layer underneath may act to prevent diffusion of allurin into $\mathrm{J} 1$ thereby redirecting it back into the surrounding media (Xiang et al., 2005).

The allurin gradient, rapidly established after spawning, must be detected and responded to by sperm to result in effective chemoattraction. Our current goal is to characterize the binding of allurin to the sperm surface and the behavioral changes that sperm exhibit in response to this protein. One approach is to conjugate Oregon Green 488 to allurin using an amine-reactive derivative. Fluorescent allurin is then used to assess binding of allurin to individual sperm by fluorescence microscopy and to sperm populations by flow cytometry. As shown in Fig. 5B, 

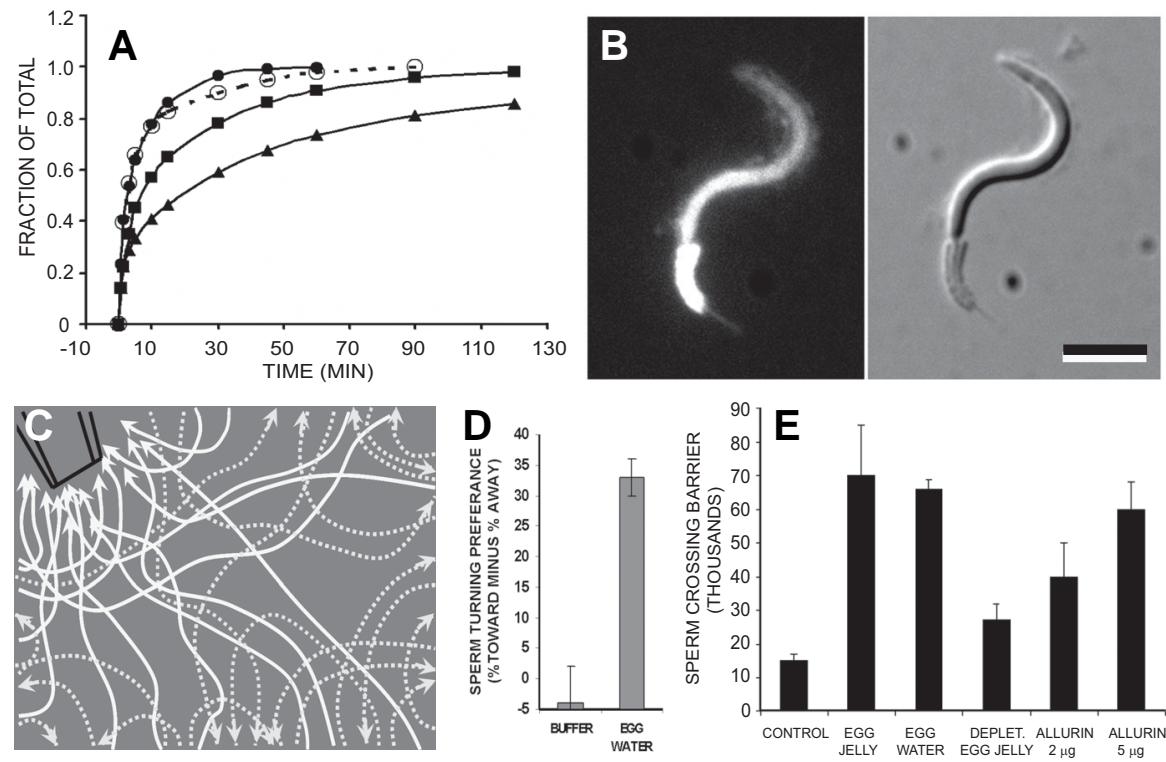

Fig. 5. Sperm responses to allurin. (A) Release of allurin from the egg into the surrounding medium occurs rapidly with a half time of 4 minutes lopen circles). Release appears to involve both diffusion and convection. Based on computer modeling, diffusion alone is slower (solid triangles; half time 20 minutes), intermittent convection faster (solid squares, half time 10 minutes) and continuous mixing best approximating allurin release (solid circles, half time 4 minutes). From Xiang et al., Mol. Reprod. Dev. 70:34460 (2005) with copyright permission from John Wiley and Sons. (B) Binding of Oregon Green-conjugated allurin to the midpiece and head of $\mathrm{X}$. laevis sperm (left). Very little binding is observed on the flagellum. A phase contrast image of the same sperm is shown on the right. Bar, $5 \mu \mathrm{m}$. (C,D) Trajectories of X. laevis sperm surrounding a capillary filled with concentrated egg water. Sperm turning toward the pipette (solid lines) outnumber those turning away (dashed lines) as shown quantitatively in panel (D). From Al-

Anzi and Chandler, Dev. Biol. 198:366-375. (1998) with copyright permission from Elsevier Science. (E) Allurin-mediated chemotaxis byX. laevis sperm as measured in a two-chamber assay. Both solubilized egg jelly and egg water elicit $~ 5$ fold greater sperm passage across a porous membrane than do controls. Purified X. laevis allurin stimulates sperm passage to a similar extent while jelly depleted of allurin exhibits reduced activity.

microscopic examination indicates that allurin binds to the midpiece and the head of Xenopus sperm with the midpiece exhibiting the highest intensity. In flow cytometry, an intense allurin signal is detected that is an order of magnitude above back ground despite the fact that the surrounding solution contained free allurin in order to keep bound allurin from dissociating from its receptors on the sperm surface (L. Burnett, unpublished data).

Sperm behavioral responses to allurin have been assayed in three ways (Sugiyama et al., 2005). First, tracking of sperm in the vicinity of a capillary filled with concentrated egg water showed that many sperm turned toward and swam to the source of chemoattractant (solid arrows, Fig. 5C) while in the absence of chemoattractant no turning preference could be detected (Fig. 5D). Second, we made quantitative comparisons using a "twochamber" assay in which sperm cross a polycarbonate membrane having pores of defined size in response to a chemotactic gradient and are then counted in the receiving chamber. Using such an assay, one finds that placement of a small drop of solubilized egg jelly in the receiving chamber results in passage of over 5 times as many sperm through the membrane as in controls with buffer alone (see Fig. 5E). Similar sperm attractant activity is seen in egg water as expected due to rapid diffusion of allurin from jelly into medium (3rd bar, Fig. 5E). Solubilized jelly from eggs depleted of allurin in this manner show a considerably reduced activity (fourth bar, Fig. 5E). Allurin purified to homogeneity exhibits similar activity in these assays at lower doses as expected (5th and 6th bars, Fig. 5E).

Although the two-chamber assay provides useful information about sperm movement as a population we wanted to further investigate sperm behavior at the microscopic level. To do this we employed a chamber designed by Zigmond for use with neutrophils, but later applied successfully to mammalian sperm chemotaxis by Giojalas and colleagues (Fabro et al., 2002)). The chamber contains two troughs, one acting as a sperm reservoir, the other as a chemoattractant reservoir, separated by a $1 \mathrm{~mm}$ - wide bridge. The movement of sperm in response to the chemoattractant gradient formed is monitored in the bridge area by video microscopy. Sperm can then be tracked to acquire quantitative data for velocity and direction. Using this assay we have determined that allurin is chemotactic and not chemokinetic. Sperm incubated with egg water showed no increase in average velocity compared to sperm incubated with buffer alone; however, in tracking 50 individual sperm, a 3.5-fold increase in distance traveled toward the chemoattractant trough was seen in the presence of egg water as compared to buffer even though total distance traveled remained the same (Burnett, unpublished observations). These data indicate that allurin elicits a change in direction rather than a change in motility from Xenopus sperm.

Since species specificity and mechanisms of chemoattraction can vary dramatically, we asked whether allurin-like chemotaxis systems might be present in other species. Indeed, we find that egg water from a closely related species, Xenopus tropicalis, exhibits sperm chemoattractant activity and contains an antiallurin cross-reactive protein that is approximately $20 \mathrm{kD}$ and is fully active upon purification (Burnett et al., 2008). Expressed sequence tag databases indicate that transcripts coding for a protein very similar to allurin are produced in the oviduct. Indeed, subsequent RT-PCR showed that this transcript is present and we cloned the full-length transcript from oviductal cDNA. Recombinant forms of this protein synthesized in mammalian cell culture demonstrate the same molecular weight and cross-reactivity as the protein found in Xenopus tropicalis egg water. Blatting of this sequence against the $X$. tropicalis genome indicates that the transcript encoding this protein corresponds to a previously unannotated region of the genome. Therefore, we designate this protein as Xt allurin and its newly discovered gene as Crisp A.

In addition to Crisp A, other CRISP family members have been identified in the Xenopus tropicalis genome, two of which have been annotated: Crisp 2 and Crisp 3. Other Crisp family members with mammalian homologs can be identified including the high 
molecular weight members Crisp LD1 and Crisp LD2. We have examined expression of these genes in male and female reproductive tissues including testis, ovary, oviduct and eggs of $X$. tropicalis and our results are summarized in Table 3. Crisp A is the only Crisp gene expressed in the oviduct while Crisp LD1 and Crisp LD2 are expressed in the ovary. As anticipated, no Crisp genes are expressed in the Xenopus egg confirming the fact that allurin is not egg-derived but rather oviduct-derived. Interestingly, Crisp family members are also expressed in the testes; in fact, Crisp 2, Crisp 3, Crisp LD1, and Crisp LD2 are all expressed in this tissue. This suggests a possible conservation of Crisp family protein roles in the male reproductive tract of frog since these proteins are known to participate in sperm gametogenesis and gamete interactions in mammals.

Our findings suggest an additional conservation of function among allurins. Despite the fact that allurin from $X$. laevis and allurin from $X$. tropicalis exhibit only $62 \%$ sequence identity and these proteins differ in the position of two of their 10 conserved cysteines, both proteins actually show a high interspecies chemotactic activity. Egg water and purified allurin from each species typically elicits a response from heterospecific sperm that is a minimum of $70 \%$ of that achieved with sperm of the same species (Burnett et al., 2008). This suggests a relative promiscuity of chemoattractants between species and portends a possibly broader evolutionary conservation of an allurin-mediated mechanism of sperm chemoattraction.

\section{Mammalian crisps and chemoattraction}

Allurin's ability to elicit interspecies chemotaxis is reminiscent of the ability of follicular fluid to induce cross-species chemotaxis in mammals. Furthermore, we have recently accumulated a growing body of evidence that Crisp proteins are expressed in the female reproductive tract of mammals and that allurin-mediated chemotaxis may occur in mammals as well as amphibians (Burnett et al., 2006).

First, two-chamber in vitroassays demonstrate that allurin can elicit chemotaxis in mouse sperm. The number of sperm passing into the bottom chamber was on average three times greater in the presence of allurin compared to buffer alone (Burnett, unpublished observations). This assay cannot accurately assess what specific changes in sperm behavior are occurring and could include both chemotactic and chemokinetic components. Currently we are using a sperm tracking assay to assess specific sperm behaviors in the presence of allurin.
As one would predict, allurin conjugated to Oregon Green 488 is able to bind to mouse sperm. Binding is seen specifically in the post acrosomal region of the head and the midpiece. This labeling is unique compared to that of Crisp 1 and 2 binding to rat sperm which localizes to the head, tail, and acrosome (Rochwerger and Cuasnicu, 1992). These data indicate that allurin can bind to the mouse sperm surface and elicit chemotaxis in vitro suggesting that allurin-mediated chemotactic behavior may be possible in mammalian systems. Whether chemotaxis of mammalian sperm to allurin-like proteins occurs in vivo remains to be determined.

Follicular fluid has been identified consistently as a sperm chemoattractant for mammalian sperm and this fluid is thought to be produced by cells derived from the ovary. Eisenbach and colleagues have found that human cumulus cell-culture media can elicit chemotaxis in human sperm (Sun et al., 2005). This finding suggests that cumulus cells are likely to produce and secrete a mammalian sperm chemoattractant. With this in mind we have investigated expression of mammalian Crisp genes in female reproductive tissues of mice using semi-quantitative RTPCR. We find that a number of Crisp family genes are expressed in the female reproductive tract of mice; Crisp 1 and Crisp LD 2 are both expressed in high levels in the ovary as well as in cumulus oophorus cells. Crisp LD1 appears to be expressed exclusively in the ovary. Crisp 2, Crisp 3, and Crisp 4 show little to no expression in female reproductive tissues. Further studies using immunocytochemistry demonstrate that anti-allurin antibodies (which cross-react with other Crisp proteins) label both mural and oophorus cumulus cells in early antral follicles (L. Burnett, unpublished observations).

These findings lay groundwork for the possibility that Crisp family proteins may play critical roles in female gametogenesis in addition to their involvement in male gametogenesis. Although Crisp 1 and Crisp LD2 are both predicted to have significantly higher molecular weights than allurin it is clear from previous studies of Crisp 1 that this protein can be processed into multiple different forms including a truncated form lacking the CRD domain that would be structurally similar to amphibian allurins. Currently we are examining whether allurin-like proteins can be found and identified in mouse follicular fluid to support conservation of an allurin-mediated chemotaxis model in mouse.

Thus, our studies and those of other laboratories lead to several well defined and testable hypotheses. First, the mammalian follicle (likely the cumulus cells) produces Crisp proteins that not only bathe the developing oocyte but also accumulate in the follicular fluid. Second, Crisp proteins or their truncated products

TABLE 3

EXPRESSION PATTERNS OF CRISP PROTEINS IN THE MALE AND FEMALE REPRODUCTIVE TRACTS

\begin{tabular}{|c|c|c|c|c|c|c|}
\hline Animal & Testis & Epididymis & Male accesory glands & Ovary & Oviduct & Egg / Cumulus complex \\
\hline$X$. laevis & ND & Not applicable & Not applicable & Allurin? (low levels) & \multicolumn{2}{|c|}{ Allurin (presumably Crisp A) ND } \\
\hline$X$. tropicalis & Crisp 2,3, LD1, LD3 & Not applicable & Not applicable & Crisp 1, LD2 & Crisp A & None \\
\hline M. musculus & Crisp 2 & Crisp 1, 4 & ND & $\begin{array}{l}\text { Crisp 1, LD1, LD2 } \\
\text { Crisp } 3 \text { (low levels) }\end{array}$ & $\begin{array}{l}\text { Crisp 1, 2, LD1, LD2, } 3 \text { (low } \\
\text { levels) }\end{array}$ & $\begin{array}{l}\text { Crisp 1, LD2 } \\
\text { Crisp } 3 \text { (low levels) }\end{array}$ \\
\hline R. norvegicus & Crisp 2 & Crisp 1,4 & ND & ND & ND & ND \\
\hline E. caballus & Crisp 2 & Crisp 1 & Crisp 3 (seminal plasma) & ND & ND & ND \\
\hline H. sapiens & Crisp 2 & $\begin{array}{l}\text { Crisp } 1 \text { long, } \\
\text { Crisp } 1 \text { short, Crisp } 3 \\
\text { Crisp } 4\end{array}$ & Crisp 3 (prostate) & ND & ND & ND \\
\hline
\end{tabular}


in the follicular fluid are released at ovulation and are disseminated as the ovum proceeds down the oviduct. Third, sperm sensing these Crisp products respond by chemotaxis toward the egg. Fourth, Crisp protein products either from the sperm or from those cached in the ovum play a role in sperm-egg binding and fusion.

Future studies in Crisp family proteins may elucidate additional events involved in sperm and egg maturation, mammalian sperm chemotaxis, and sperm-egg interaction providing us with a broader understanding of multiple fertilization mechanisms.

\section{Acknowledgements}

We thank the W. M. Keck Bioimaging Laboratory for use of their Leica NTS laser scanning confocal microscopy unit and their video microscopy equipment. We would also like to thank the Life Sciences Electron Microscopy Facility for use of their Phillips CM12S transmission electron microscope. These studies were supported by grants from the National Science Foundation, most recently IOS 0615435.

\section{References}

AL-ANZI, B. and CHANDLER, D. (1998). Xenopus laevisegg jelly releases a sperm chemoattractant during spawning. Dev Bio/198: 366-375.

ASOJO, O.A., GOUD, G., DHAR, K., LOUKAS, A., ZAHN, B., DEUMIE, V., LUI, S., BORGSTAHL, G.E., and HOTEZ, P.J. (2005). X-ray structure of Na-ASP-2, a pathogenesis-related protein from the nematode parasite, Necator americanus, and a vaccine antigen for human hookworm infection. JMo/ Bio/346: 801-814.

BABCOCK, R. (1995). Synchronous multi-specific spawning on coral reefs: potential for hybridization and roles of gamete recognition. Reprod Fertil Dev7: 94350

BJARTELL, A., JOHANSSON, R., BJORK, T., GADELEANU, V., LUNDWALL, A., LILJA, H., KJELDSEN, L., and UDBY, L. (2006). Immunohistochemical detection of cysteine-rich secretory protein 3 in tissue and in serum from men with cancer or benign enlargement of the prostate gland. Prostate 66: 591-603.

BOHMER, M., VAN, Q., WEYAND, I., HAGEN, V., BEYERMANN, M., MATSUMOTO, M.L., HOSHI, M., HILDEBRAND, E.L., and KAUPP, U.B. (2005). Calcium spikes in the flagellum control chemotactic behavior of sperm. EMBO J 24 : 2741-2752.

BOLAND, W. (1995). The chemistry of gamete attraction: Chemical structures, biosynthesis, and (a)biotic degradation of algal pheromones. Proc Nat/ Acad SCi USA 92: 37-43.

BROKAW, C.J. (1999). Bending patterns of ATP-reactivated sea urchin sperm flagella following high salt extraction for removal of outer dynein arms. Cel/ Motil Cytoskeleton 42: 125-33.

BROKAW, C.J. (2002). Computer simulation of flagellar movement VIII: coordination of dynein by local curvature control can generate helical bending waves. Cell Motil Cytoskeleton 53: 103-24.

BROKAW, C.J. (1979). Calcium-induced asymmetrical beating of tritondemembranated sea urchin sperm flagella. J Cell Bio/82: 401-11.

BROWN, R.L., HALEY, T.L., WEST, K.A., and CRABB, J.W. (1999). Pseudechetoxin: a peptide blocker of cyclic nucleotide-gated ion channels. Proc Nat/ Acad SCi USA 96: 754-9.

BURNETT, L.A., BIEBER, A.L, and CHANDLER, D.E (2006). Allurin, a sperm chemoattractant from amphibians, binds to mouse sperm and elicits chemotaxis in vitro. Abstract \#1192 Program notes, Annual Meeting of the American Society for Cell Biology.

BURNETT, L.A., BOYLES, S., SPENCER, C., BIEBER, A.L., and CHANDLER, D.E. (2008). Xenopus tropicalis allurin: expression, characterization and sperm chemoattractant activity. Dev. Biol. 316: 408-416.

BUSSO, D., COHEN, D.J., HAYASHI, M., KASHARA, M., and CUASNICU, P.S. (2005). Human testicular protein TPX1/CRISP 2: localization in spermatozoa, fate after capacitation and relevance for gamete interaction. Mol Hum Reprod 11: 299-305.

BUSSO, D., COHEN, D.J., MALDERA, J.A., DEMATTEIS, A., CUASNICU, P.S. (2007a). A novel function for CRISP1 in rodent fertilization: involvement in sperm-zona pellucida interaction. Biol Reprod 77: 848-854.

BUSSO, D., GOLDWEIC, N., HAYASHI, M., KASHARA, M., and CUASNICU, P.S. (2007b). Evidence for the involvement of testicular protein CRISP2 in mouse sperm-egg fusion. Biol Reprod 76:701-8.

CASTANEDA, O., SOTOLONG, O.V., AMOR, A.M., STOCKLIN, R., ANDERSON, A.J., HARVEY, A.L., ENGSTROM, A., and KARLSSON, E. (1995). Characterization of a potassium channel toxin from the Caribbean Sea anemone Stichodactyla helianthus. Toxicon 33: 603-13.

CHANDLER, D.E., and ROBERSON, R.W. (2008) Bioimaging: Current Concepts in Light and Electron Microscopy, Jones and Bartlett, Sudbury, in press.

CLARK, H.F., GURNERY, A.L, ABAYA, E., BAKER, K. and BALDWIN, D. (2003). The secreted protein discovery initiative (SPDI), a large-scale effort to identify novel human secreted and transmembrane proteins: a bioinformatics assessment. Genome Res 13: 2265-2270.

COHEN, D.J., ELLERMAN, D.A., BUSSO, D., MORGENFELD, M.M., PIAZZA, A.D., HAYASHI, M., YOUNG, E.T., KASAHARA, M., and CUASNICU, P.S. (2001). Evidence that human epididymal protein ARP plays a role in gamete fusion through complementary sites on the surface of the human egg. Biol Reprod 65: 1000-5.

COHEN, D.J., DA ROS, V.G, BUSSO, D., ELLERMAN, D.A., MALERA, J., GOLDWEIC, N., and CUASNICU, P.S. (2007). Participation of epididymal cysteine-rich secretory proteins in sperm-egg fusion and their potential use for male fertility regulation. Asian J Andro/9: 528-32.

COHEN, D.J., ELLERMAN, D.A., and CUASNICU, P.S. (2000a). Mammalian sperm-egg fusion: evidence that epididymal protein DE plays a role in mouse gamete fusion. Biol Reprod63:462-8.

COHEN, D.J., ROCHWERGER, L., ELLERMAN, D.A., MORGENFELD, M.M., BUSSO, D., and CUASNICU, P.S. (2000b). Relationship between the association of rat epididymal protein «DE» with spermatozoa and the behavior and function of the protein. Mol Reprod Dev 56:180-8.

COHEN, D.J., MUNUCE, M.J., and CUASNICU, P.S. (1996). Mammalian spermegg fusion: the development of rat oolemma fusibility during oogenesis involves the appearance of binding sites for sperm protein «DE». Biol Reprod55: 2006.

COHEN-DAYAG, A., TUR-CASPA, I., DOR, J., MASHIACH, S., and EISENBACH, M. (1995). Sperm capacitation in humans is transient and correlates with chemotactic responsiveness to follicular factors. Proc Nat/ Acad Sci USA 92: 11039-11043.

COOK, S.P., BROKAW, C.J., MULLER, C.H., and BABCOCK, D.F. (1994). Sperm chemotaxis: egg peptides control cytosolic calcium to regulate flagellar responses. Dev Bio/165:10-9.

COTTON, J., CREST, M., COUET, F., ALESSANDRI, N., GOLA, M., FOREST, E., KARLSSON, E., VITA, C., and MENEZ, A. (1997). A potassium-channel toxin from the sea anemone Bunodosoma granulifera, an inhibitor for Kv1 channels. Revision of the amino acid sequence, disulfide-bridge assignment, chemical synthesis, and biological activity. Eur J Biochem 244: 192-202.

DACHEUX, J.L., BELGAZI, M., LANSON, Y., and DACHEUX, F. (2006). Human epididymal secretome and proteome. Mol Cel/ Endocrino/250: 36-42.

DA ROS, V., BUSSO, D., COHEN, D.J., MALERA, J., GOLDWEIC, N., and CUASNICU, P.S. (2007). Molecular mechanisms involved in gamete interaction: evidence for the participation of cysteine-rich secretory proteins (CRISP) in sperm-egg fusion. Soc Reprod Fertil Supp/65: 353-6.

DA ROS, V.G., MUNUCE, M.J., COHEN, D.J., MARIN-BRIGGILER, C.I., BUSSO, D., VISCONTI, P.E., and CUASNICU, P.S. (2004). Bicarbonate is required for migration of sperm epididymal protein DE (CRISP 1 ) to the equatorial segment and expression of rat sperm fusion ability. Biol Reprod 70: 1325-32.

DANGOTT, L.J., JORDAN, J.E., BELLET, R.A., and GARBERS, D.L. (1989). Cloning of the mRNA for the protein that crosslinks to the egg peptide speract. Proc Natl Acad Sci USA. 86: 2128-32.

DARSZON, A., TREVINO, C.L., WOOD, C., GALINDO, B., RODRIGUEZ-MIRANA, E., ACEVEDO, J.J., HERNANDEZ-GONZALEZ, E.O., BELTRAN, C., MARTINEZ-LOPEZ, P., and NISHIGAKI, T. (2007). Ion channels in sperm motility and capacitation. Soc Reprod Fertil Supp/65: 229-44.

DARSZON, A., TREVINO, C.L., WOOD, C., GALINDO, B., RODRIGUEZ-MIRANA, E., ACEVEDO, J.J., HERNANDEZ-GONZALEZ, E.O., BELTRAN, C., 
MARTINEZ-LOPEZ, P., and NISHIGAKI, T. (2006). Sperm channel diversity and functional multiplicity. Reproduction 131: 977-88.

EBERSPAECHER, U., ROOSTERMAN, D., KRATZSCHMAR, J., HAENDLER, B., HABENICHT, U.F., BECKER, A., QUENSEL, C., PETRI, T., SCHLEUNING, W.D., and DONNER, P. (1995) Mouse androgen-dependent epididymal glycoprotein CRISP 1 (DE/AEG): isolation, biochemical characterization, and expression in recombinant form. Mol Reprod Dev 42: 157-72

EISENBACH, M., and GIOJALAS, L. (2006). Sperm guidance in mammals - an unpaved road to the egg. Nature Rev Mol Cell Bio/7: 276-285.

EISENBACH, M.A. (2007). A hitchhiker's guide through advances and conceptual changes in chemotaxis. J Cell Physiol. 213: 574-580.

ELLERMAN, D.A., BRANTUA, V.S., MARTINEZ, S.P., COHEN, D.J., CONESA, D., and CUASNICU, P.S. (1998). Potential contraceptive use of epididymal proteins: immunization of male rats with epididymal protein DE inhibits sperm fusion ability. Biol Reprod 59: 1029-36.

ELLERMAN, D.A., COHEN, D.J., DA ROS, V.G., MORGENFELD, M.M., BUSSO, D., and CAUSNICU, P.S. (2006). Sperm protein «DE» mediates gamete fusion through an evolutionarily conserved site of the CRISP family. Dev Bio/297: 22837.

ELLERMAN, D.A., BUSSO, D., MALDERA, J.A., and CUASNICU, P.S. (2008). Immunocontraceptive properties of recombinant sperm protein $D E$ : implications for the development of novel contraceptives. Fertil Steril. 89: 199-205.

EVANS, J.P., and FLORMAN, H.M. (2002). The state of the union: the cell biology of fertilization. Nature Cel/ Bio/4: s57-s63.

FABRO, G., ROVASIO, R.A., CIVAlERO, S., FRENKEL, A., CAPLAN, S.R., EISENBACH, M., and GIOJALAS, L.C. (2002). Chemotaxis of capacitated rabbit spermatozoa to follicular fluid revealed by a novel directionality-based assay. Biol Reprod67: 1565-71

FERNANDEZ, C., SZYPERSKI, T., BRUYERE, T., RAMAGE, P., RAMAGE, P., MOSINGER, E., and WUTHRICH, K. (1997). NMR solution structure of the pathogenesis-related protein P14a. J Mo/ Bio/266: 576-593.

FOSTER, G.A. and GERTON, J.A. (1996) Autoantigen 1 of the guinea pig sperm acrosome is the homologue of mouse Tpx-1 and human TPX1 and is a member of the cysteine-rich secretory protein (CRISP) family. Mol Reprod Dev 44: 221 229.

FUKUDA, N., YOMOGIDA, K., OKABE, M., and TOUHARA, K. (2004). Functional characterization of a mouse testicular olfactory receptor and its role in chemosensing and in regulation of sperm motility. J Cell Sci117: 5835-45.

GARBERS, D.L. (1989). Guanylate cyclase, a cell surface receptor. J Biol Chem 264: 9103-6.

GARBERS, D.L., KOESLING, D., and SCHULTZ, G. (1994). Guanylyl cyclase receptors. Mol Biol Cel/5:1-5.

GIBBS, G.M., and O'BRYAN, M.K. (2007). Cysteine rich secretory proteins in reproduction and venom. Soc Reprod Fertil Supp/65: 261-7.

GIBBS, G.M., SCANLON, M.J., SWARBRICK, J., CURTIS, S., GALLANT, E., DULHUNTY, A.F., and O'BRYAN, M.K. (2006). The cysteine-rich secretory protein domain of Tpx-1 is related to ion channel toxins and regulates ryanodine receptor calcium signaling. J Biol Chem 281: 4156-4163.

GIOJALAS, L.C., AND ROVASIO, R.A. (1998). Mouse spermatozoa modify their motility parameters and chemotactic response to factors from the oocyte microenvironment. Int $J$ Andro/21: 201-6.

GUO, M. TENG, M. NIU, L., LIU, Q., HAUANG, Q. and HAO, Q. (2005). Crystal structure of the cysteine-rich secretory protein stecrisp reveals that the cysteine-rich domain has $\mathrm{K}+$ channel inhibitor-like fold. J Biol Chem 280: 1240512412.

HAENDLER, B., KRATZSCHMAR, J., THEURING, J., AND SCHLEUNING, W.D (1993). Transcripts for cysteine-rich secretory protein-1 (CRISP 1; DE/AEG) and the novel related CRISP 3 are expressed under androgen control in the mouse salivary gland. Endocrinology 133: 192-8.

HAMANN, H., JUDE, R., SIEME, H., MERTENS, U., TOPFER-PETERSEN, E. DISTL, O., and LEEB, T. (2007). A polymorphism within the equine CRISP3 gene is associated with stallion fertility in Hanoverian warm-blooded horses. Anim Genet 38: 259-64.

HAYAHSI, M., FUJIMOTO, S., TAKANO, H., USHIKI, T., ABE, K., ISHIKURA, H., YOSHIDA, M.C., KIRCHOFF, C., ISHIBASHI, T., and KASAHARA, M. (1996). Characterization of a human glycoprotein with a potential role in sperm-egg fusion: cDNA cloning, immunohistochemical localization, and chromosomal assignment of the gene (AEGL1) Genomics 32: 367-374

HARDY, D.M., HUANG, T.T., DRISCOLL, W.J., TUNG, G.C., and WILD, G.C. (1988). Purification and characterization of the primary acrosomal autoantigen of guinea pig epididymal spermatozoa. Biol Reprod38: 423-437.

HENRIKSEN, A., KING, T.P., MIRZA, O., MONSLAVE, R.I., MENO, K. IPSEN, H. LARSEN, J.N., GAJHEDE, M. and SPANGFORT, M.D. (2001). Major venom allergen of yellow jackets, Ves $v 5$ : structural characterization of a pathogenesis-related superfamily. Proteins 45: 438-448

HOODBURY, T., and DEAN, J. (2004). Insights into the molecular basis of spermegg recognition in mammals. Reproduction 127: 417-422.

ISHIKAWA, M., TSUTSUI, H., COSSON, J., OKA, Y., and MORISAWA, M. (2004). Strategies for sperm chemotaxis in the siphonophores and ascidians: a numerical simulation study. Biol Bul/206: 95-102.

JALKANEN, J., HUHTANIEMI, I., and POUTANEN, M. (2005). Mouse cysteine-rich secretory protein 4 (CRISP4): a member of the Crisp family exclusively expressed in the epididymis in an androgen-dependent manner. Biol Reprod72 1268-74.

KATIGRI, CH. (1987). The role of oviductal secretions in mediating gamete fusion in anuran amphibians. Zool Sci4: 1-14.

KAUPP, U.B., SOLZIN, J., HILDEBRAND, E., BROWN, J.E., HELBIG, A., HAGEN, V., BEYERMANN, M., PAMPALONI, F., and WEYAND, I. (2003). The signal flow and motor response controlling chemotaxis of sea urchin sperm. Nat Cell Biol5: 109-17.

KAUPP, U.B., HILDEBRAND, E., and WEYAND, I. (2006). Sperm chemotaxis in marine invertebrates-molecules and mechanisms. J Cell Physio/208: 487-94.

KIRCHHOFF, C. (1998). Molecular characterization of epididymal proteins. Rev Reprod 3: 86-95.

KIRKMAN-BROWN, J.C., PUNT, E.L., BARRATT, C.L., AND PUBLICOVER, S.J. (2002). Zona pellucida and progesterone-induced $\mathrm{Ca} 2+$ signaling and acrosome reaction in human spermatozoa. $J$ Andro/23: 306-15.

KRATZCHMAR, J., HAENDLER, B., EBERSPAECHER, U., ROOSTERMAN, D., DONNER, P., and SCHLEUNING, W.D. (1996). The human cysteine-rich secretory protein (CRISP) family. Primary structure and tissue distribution of CRISP 1, CRISP 2 and CRISP 3. Eur J Biochem 236: 872-836.

MAEDA, M., SAKASHITA, Y., OHBA, Y., and NAKANISHI, T. (1998). Molecular cloning of the rat Tpx-1 responsible for the interaction between spermatogenic and Seritoli cells. Biochem Biophys Res Comm 248: 140-146.

MATSUMOTO, M., SOLZIN, J., HELBIG, A., HAGEN, V., UENO, S., HAWASE, O. MARUYAMA, Y., OGISO, M., GODDE, M., MINKATA, H., KAUPP, B., and HOSHI, M. (2003) A sperm-activating peptide controls a cGMP-signaling pathway in starfish sperm. Dev Bio/260: 314-324.

MILLER, R.L., and VOGT, R. (1996). An N-terminal partial sequence of the $13 \mathrm{kDa}$ Pycnopodia helianthoides sperm chemoattractant 'startrak' possesses spermattracting activity. J Exp Bio/199: 311-8.

MILLER, R.L. (1997). Specificity of sperm chemotaxis among great barrier reef shallow-water Holothurians and Ophiuroids. J Exp Zoo/279: 189-200.

MILLER, R. (1985). Sperm chemo-orientation in the metazoa. In Biology of Fertilization (Metz, C. and Monroy, A., eds.), Vol. 2, pp. 275-337, Academic Press, New York.

MORITA, M., NISHIKAWA, A., NAKAJIMA, A., IGUCHI, A., SAKAI, D., TAKEMURA A., and OKUNO, M. (2006). Eggs regulate sperm flagellar motility initiation, chemotaxis and inhibition in the coral Acropora digitifera, A. gemmifera and A tenuis. J Exp Bio/209: 4574-9.

MORRISSETTE, J., KRATZSCHMAR, J., HAENDLER, B., EL-HAYEK, R., MOCHCA-MORALES, J., MARTIN, B.M., PATEL, J.R., and MOSS, R.L. (1995) Primary structure and properties of helothermine, a peptide toxin that blocks ryanodine receptors. Biophys $J 68$ : 2280-8.

MULLER, D.G., GASSMANN, G., BOLAND, W., and JAENICKE, L. (1982). The sperm attractant of marine brown alga Ascophyllum nodosum (Phaeophyceae). Science 218: 1119-20.

NEILL, A.T., and VACQUIER, V.D. (2004). Ligands and receptors mediating signal transduction in sea urchin spermatozoa. Reproduction 127: 141-149.

NISHIGAKI, T., CHIBA, K., MIKI, W. and HOSHI, M. (1996). Structure and function of asterosaps, sperm-activating peptides from the jelly coat of starfish eggs. Zygote 4: 237-245. 
NOBILE, M., NOCETI, F., PRESTIPINO, G., and POSSANI, L.D. (1996). Helothermine, a lizard venom toxin, inhibits calcium current in cerebellar granules. Exp Brain Res 110: 15-20.

NOBILE, M., MAGNELLI, V., LAGOSTENA, L., MOCHCA-MORALES, J., POSSANI, L.D., and PRESTIPINO, G. (1994). The toxin helothermine affects potassium currents in newborn rat cerebellar granule cells. J Membr Bio/139: 49-55.

NOLAN, M.A., WU, L., BANG, H.J., JELINSKY, S.A., ROBERTS, K.P., TURNER, T.T., KOPF, G.S., and JOHNSTON, D.S. (2006). Identification of rat cysteinerich secretory protein 4 (Crisp 4) as the ortholog to human CRISP 1 and mouse Crisp 4. Biol Reprod 74: 984-91.

O'BRYAN, M.K., SEBIRE, K., MEINHARDT, A., EDGAR, K., KEAH, H.H., HEARN, M.T., and DE KRETSER, D.M. (2001). Tpx-1 is a component of the outer dense fibers and acrosome of rat spermatozoa. Mol Reprod Dev 58: 11625.

ODA, S., IGARASHI, Y., MANAKA, K., KOIBUCHI, N., SAKI-SAWADA, M., SAKAI, K., MORISAWA, M., OHTAKE, H., and SHIMIZU, N. (1998). Sperm-activating proteins obtained from the herring eggs are homologous to trypsin inhibitors and synthesized in follicle cells. Dev Bio/204: 55-63.

OLIVERIA, R.G., TOMASI, L., ROVASIO, R.A., and GIOJALAS, L.C. (1999). Increased velocity and induction of chemotactic response in mouse spermatozoa by follicular and oviductal fluids. J Reprod Fertil115: 23-7.

OLSON, J.H., and CHANDLER, D.E. (1999). Xenopus laevis egg jelly contains small proteins that are essential to fertilization. Dev Bio/210: 401-10.

OLSON, J., XIANG, X., ZIEGERT, T., KITTLESON, A., RAWLS, A., BIEBER, A., and CHANDLER, D.E. (2001). Allurin, a $21 \mathrm{kD}$ sperm chemoattractant from Xenopus egg jelly, is homologous to mammalian sperm-binding proteins. Proc Natl Acad Sci USA 98: 11205-11210.

PRIMAKOFF, P., and MYLES, D.G. (2002). Penetration, adhesion, and fusion in mammalian sperm egg interaction. Science 296: 21835.

RALT, D., GOLDENBERG, M., FETTEROLF, P., THOMPSON, D., DOR, J., MASHIACH, S., GARBERS, D.L., and EISENBACH, M. (1991). Sperm attraction to a follicular factor(s) correlates with human egg fertilizability. Proc Nat/ Acad Sci USA. 88: 2840-4.

RIFFELL, J.A., KRUG, P.J., and ZIMMER, R.K (2004). The ecological and evolutionary consequences of sperm chemoattraction. Proc Nat/ Acad Sci USA 101: 4501-6.

RIFFELL, J.A., KRUG, P.J., and ZIMMER, R.K. (2002). Fertilization in the sea: the chemical identity of an abalone sperm attractant. J Exp Bio/205: 143950.

ROBERTS, K.P., ENSRUD, K.M., WOOTERS, J.L., NOLAN, M.A., JOHNSTON, D.S., and HAMILTON, D.W. (2006). Epididymal secreted protein Crisp 1 and sperm function. Mol Cell Endocrino/250: 122-7.

ROBERTS, K.P., JOHNSTON, D.S., NOLAN, M.A., WOOTERS, J.L., WAXMONSKY, N.C., PIEHL, L.B., ENSRUD-BOWLIN, K.M., and HAMILTON, D.W. (2007). Structure and function of epididymal protein cysteine-rich secretory protein-1. Asian J Andro/9: 508-14.

ROBERTS, K.P., WAMSTAD, J.A., ENSRUD, K.M., and HAMILTON, D.W. (2003). Inhibition of capacitation-associated tyrosine phosphorylation signaling in rat sperm by epididymal protein Crisp 1. Biol Reprod 69: 572-81.

ROBERTS, K.P., ENSRUD, K.M., and HAMILTON, D.W. (2002). A comparative analysis of expression and processing of the rat epididymal fluid and spermbound forms of proteins D and E. Biol Reprod 67: 525-33.

ROBERTS, K.P., HOFFMAN, L.B., ENSRUD, K.M., and HAMILTON, D.W. (2001). Expression of Crisp 1 mRNA splice variants in the rat epididymis, and comparative analysis of the rat and mouse Crisp 1 gene regulatory regions. J Andro/22: 157-63.

ROCHWERGER, L., and CUASNICU, P.S. (1992a) Redistribution of a rat sperm epididymal glycoprotein after in vivo and in vitro capacitation. Mol Reprod Dev 31: 34-41.

ROCHWERGER, L., COHEN, D.J., and CUASNICU, P.S. (1992b). Mammalian sperm-egg fusion: the rat egg has complementary sites for a sperm protein that mediates gamete fusion. Dev Bio/153: 83-90.

SCHAMBONY, A., HEFELE, J.A., GENTZEL, M., WILM, M., and WEDLICH, D. (2003). A homologue of cysteine-rich secretory proteins induces premature degradation of vitelline envelopes and hatching of Xenopus laevis embryos. Mech Dev 120: 937-48.

SCHAMBONY, A., HESS, O., GENTZEL, M., and TOPFER-PETERSEN, E. (1998). Expression of CRISP proteins in the male equine genital tract. $J$ Reprod Fertil
Supp/53: 67-72.

SCHAMBONY, A., GENTZEL, M., WOLFES, H., RAIDA, M., NEUMANN, U., and TOPFER-PETERSEN, E. (1998). Equine CRISP 3: primary structure and expression in the male genital tract. Biochim Biophys Acta 1387: 206-16.

SCHWIDETZKY, U., HAENDLER, B., and SCHLEUNING, W.D. (1995). Isolation and characterization of the androgen-dependent mouse cysteine-rich secretory protein-3 (CRISP 3) gene. Biochem J309: 831-6.

SHIBA, K., MARIAN, T., KRASZNAI, Z., BABA, S.A., MORISAWA, M., and YOSHIDA, M. (2006) $\mathrm{Na}+/ \mathrm{Ca} 2+$ exchanger modulates the flagellar wave pattern for the regulation of motility activation and chemotaxis in the ascidian spermatozoa. Cell Motil Cytoskeleton 63: 623-32

SHIBA, K., OHMURO, J., MOGAMI, Y., NISHIGAKI, T., WOOD, C.D., DARSZON, A., TATSU, Y., and YUMOTO, N. (2005). Sperm-activating peptide induces asymmetric flagellar bending in sea urchin sperm. Zool Sci22: 293-9.

SHIKAMOTO, Y., SUTO, K., YAMAZAKI, Y., MORITA, T., and MIZUNO, H. (2005). Crystal structure of a CRISP family $\mathrm{Ca} 2+$-channel blocker derived from snake venom. J Mol Bio/350: 735-43.

SHIMOMURA, H., DANGOTT, L.J., and GARBERS, D.L. (1986). Covalent coupling of a resact analogue to guanylate cyclase. J Biol Chem 261: 15778-82.

SPEHR, M., SCHWANE, K., RIFFELL, J.A., ZIMMER, R.K., and HATT, H. (2006). Odorant receptors and olfactory-like signaling mechanisms in mammalian sperm. Mol Cell Endocrino/250: 128-36.

SPEHR, M., GISSELMANN, G., POPLAWSKI, A., RIFFELL, J.A., WETZEL, C.H., ZIMMER, R.K., and HATT, H. (2003). Identification of a testicular odorant receptor mediating human sperm chemotaxis. Science 299: 2054-2058.

STRUNKER, T., WEYAND, I., BONIGK, W., VAN, Q., LOOGEN, A., BROWN, J.E., KASIKAR, N., HAGEN, V., KRAUSE, E., and KAUPP, U.B. (2006). A K+selective cGMP-gated ion channel controls chemosensation of sperm. Nat Cell Bio/8: 1149-54.

SUGIYAMA, H., AL-ANZI, B., MC GAUGHEY, R., and CHANDLER, D.E. (2004). Assays for vertebrate sperm chemotaxis. In: Germ Cell Protocols, Vol.1, Sperm and oocyte analysis, Methods in Molecular Biology, H. Schatten, ed., Humana Press, Totowa, NJ, pp.27-48.

SUN, F., BAHAT, A., GAKAMSKY, A., GIRSH, E., KATZ, N., GIOJALAS, L.C, TURKASPA, I, and EISENBACH, M. (2005). Human sperm chemotaxis: both the oocyte and its surrounding cumulus cells secrete sperm chemoattractants. Hum Reprod 20: 761-7.

SUN, F., GIOJALAS, L.C., ROVASIO, R.A., TUR-KASPA, I., SANCHEZ, R., and EISENBACH, M. (2003). Lack of species-specificity in mammalian sperm chemotaxis. Dev Bio/255: 423-7.

SUZUKI, N. (1995). Structure, function and biosynthesis of sperm-activating peptides and fucose sulfate glycoconjugate in the extracellular coat of sea urchin eggs. Zool Sci12: 13-27.

SZYPERSKI, T., FERNANDEZ, C., MUMENTHALER, C., and WUTHRICH, K. (1998). Structure comparison of human glioma pathogenesis-related protein GliPR and the plant pathogenesis-related protein P14a indicates a functional link between the human immune system and a plant defense system. ProcNat/ Acad Sci USA 95: 2262-2266

TAMURA, K., DUDLEY, J., NEI, M., and KUMAR, S. (2007). MEGA4: Molecular Evolutionary Genetics Analysis (MEGA) software version 4.0. Mol Biol Evo/24: 1596-1599.

TEVES, M.E., BARBANO, F., GUIOBALDI, H.A., SANCHEZ, R., MISKA, W., and GIOJALAS, L.C. (2006). Progesterone at the picomolar range is a chemoattractant for mammalian spermatozoa. Fertil Steril86: 745-9.

TREXLER, M., BANYAI, L., and PATTHY, L. (2000). The LCCL Module. Eur J Biochem 267: 5751-7.

TOPFER-PETERSEN, E., EKHLASI-HUNDRIESER, M., KIRCHHOFF, C., LEEB, T., and SIEME, H. (2005). The role of stallion seminal proteins in fertilisation. Anim Reprod Sci89: 159-70.

TUBBS, C.E., HALL, J.C., SCOTT, R.O., CLARK, V.P., HERMON, T.L., and BAZEMORE-WALKER, C. (2002). Binding of protein D/E to the surface of rat epididymal sperm before ejaculation and after deposition in the female reproductive tract. J Andro/23: 512-21.

UDBY, L., CALAFAT, J., SORENSEN, O.E., BORREGAARD, N., and KJELDSEN, L. (2002a). Identification of human cysteine-rich secretory protein 3 (CRISP 3) as a matrix protein in a subset of peroxidase-negative granules of neutrophils 
and in the granules of eosinophils. J Leukoc Bio/72: 462-9.

UDBY, L., COWLAND, J.B., JOHNSEN, A.H., SORENSEN, O.E., BORREGAARD, N., and KJELDSEN, L. (2002b). An ELISA for SGP28/CRISP 3, a cysteine-rich secretory protein in human neutrophils, plasma, and exocrine secretions. $J$ Immunol Methods 263: 43-55.

UDBY, L., BJARTELL, A., MALM, J., EGESTEN, A., LUNDWALL, A., COWLAND, J.B., BORREGAARD, N., and KJELDSEN, L. (2005). Characterization and localization of cysteine-rich secretory protein 3 (CRISP 3 ) in the human male reproductive tract. J Andro/26: 333-42.

VILLANUEVA-DIAZ, C., ARIZS-MARTINEZ, J., BERMEJO-MARTINEZ, L., and VADILLO-ORTEGA, F. (1995). Progesterone induces human sperm chemotaxis. Fertil Steril64: 1183-1188.

VINES, C.A., YOSHIDA, K., GRIFFIN, F.J., PILLAI, M.C., MORISAWA, M., YANAGIMACHI, R., and CHERR, G.N. (2002). Motility initiation in herring sperm is regulated by reverse sodium-calcium exchange. Proc Natl Acad SCl USA 99: 2026-31.

WANG, J., SHEN, B., GUO, M., LOU, X., DUAN, Y., CHENG, X.P., TENG, M., NIU, L., LIU, L., LIU, Q., HUANG, Q., and HAO, Q. (2005). Blocking effect and crystal structure of natrin toxin, a cysteine-rich secretory protein from Naja atra venom that targets the BKCa channel. Biochemistry 44: 10145-52.

WANG, Y.L., GOH, K.X., WU, W.G., and CHEN, C.J. (2004). Purification, crystallization and preliminary $\mathrm{x}$-ray crystallographic analysis of a cysteine-rich secretory protein (CRISP) from Naja atra venom. Acta Crystallogr B Bio/60: 19121915.

WARD, G.E., BROKAW, C.J., GARBERS, D.L., and VACQUIER, V.D. (1985). Chemotaxis of Arbacia punctulata spermatozoa to resact, a peptide from the egg jelly layer. J Cel/ Bio/101: 2324-2329.

WASSARMAN, P.M., JOVINE L., and LITSCHER, E.S. (2001). A profile of fertiliza- tion in mammals. Nat Cel/ Bio/3: E59 64.

WOOD, C.D., NISHIGAKI, T., FURUTA, T., BABA, S.A., and DARSZON, A. (2005). Real-time analysis of the role of $\mathrm{Ca}(2+)$ in flagellar movement and motility in single sea urchin sperm. J Cell Biol. 169: 725-31.

WOOD, C.D., NISHIGAKI, T., TATSU, Y., YUMOTO, N., BABA, S.A., WHITAKER, M., and DARSZON, A. (2007). Altering the speract-induced ion permeability changes that generate flagellar $\mathrm{Ca} 2+$ spikes regulates their kinetics and sea urchin sperm motility. Dev Bio/306: 525-37.

XIANG, X., BURNETT, L.A., RAWLS, A., BIEBER, A.L., and CHANDLER, D.E. (2004). The sperm chemoattractant «allurin» is expressed and secreted from the Xenopus oviduct in a hormone regulated manner. Dev Bio/275: 343-355.

XIANG, X., KITTELSON, A., OLSON, J., BIEBER, A.L., and CHANDLER, D.E. (2005). Allurin, a $21 \mathrm{kD}$ sperm chemoattractant, is rapidly released from the outermost jelly layer of the Xenopus egg by diffusion and medium convection. Mol Reprod Dev 70: 344-60.

YAMAZAKI, Y., KOIKE, H., SUGIYAMA, Y., MOTOYOSHI, K., WADA, T., HISHINUMA, S., MITA, M., and MORITA, T. (2002). Cloning and characterization of novel snake venom proteins that block smooth muscle contraction. Eur $J$ Biochem 269: 2708-15.

YOSHIDA, M., INABA, K., and MORISAWA, M. (1993). Sperm chemotaxis during the process of fertilization in the ascidians Ciona savignyi and Ciona intestinalis. Dev Bio/157: 497-506.

YOSHIDA, M., MURATA, M., INABA, K. and MORISAWA, M. (2002). A chemoattractant for ascidian spermatozoa is a sulfated steroid. Proc Nat/Acad Sci USA 99: 148316.

ZATYLNY, C., MARVIN, L., GAGNON, J., and HENRY, J. (2002). Fertilization in Sepia officinalis: the first mollusk sperm-attracting peptide. Biochem Biophys Res Commun 296: 1186-93. 


\section{Related, previously published Int. J. Dev. Biol. articles}

See our recent Special Issue Developmental Biology in Poland edited by Tarkowski, Maleszewski and Kloc at: http://www.ijdb.ehu.es/web/contents.php?vol=52\&issue=2-3

See our recent Special Issue Ear Development edited by Fernando Giraldez and Bernd Fritzsch at:

http://www.ijdb.ehu.es/web/contents.php?vol=51\&issue=6-7

The role of ion fluxes in polarized cell growth and morphogenesis: the pollen tube as an experimental paradigm Erwan Michard, Filipa Alves and José A. Feijó

Int. J. Dev. Biol. (2008) 52: doi: 10.1387/ijdb.072296em

Spatial patterns formed by chemotactic bacteria Escherichia coli

Andrey A. Polezhaev, Ruslan A. Pashkov, Alexey I. Lobanov and Igor B. Petrov

Int. J. Dev. Biol. (2006) 50: 309-314

Primordial germ cell migration

Kathleen Molyneaux and Christopher Wylie

Int. J. Dev. Biol. (2004) 48: 537-543

Cell-cell signaling and adhesion in phagocytosis and early development of Dictyostelium.

E Bracco, B Pergolizzi, B Peracino, E Ponte, A Balbo, A Mai, A Ceccarelli and S Bozzaro

Int. J. Dev. Biol. (2000) 44: 733-742

Regulation of primordial germ cell development in the mouse.

M De Felici

Int. J. Dev. Biol. (2000) 44: 575-580

Effect of platelet-derived growth factor isoforms on the migration of mouse embryo limb myogenic cells.

$\mathrm{S} E$ Webb and K K Lee

Int. J. Dev. Biol. (1997) 41: 597-605

On the role of calcium during chemotactic signalling and differentiation of the cellular slime mould Dictyostelium discoideum.

D Malchow, R Mutzel and C Schlatterer

Int. J. Dev. Biol. (1996) 40: 135-139

Egg-jelly signal molecules for triggering the acrosome reaction in starfish spermatozoa.

M Hoshi, T Nishigaki, A Ushiyama, T Okinaga, K Chiba and M Matsumoto

Int. J. Dev. Biol. (1994) 38: 167-174

Cellular and molecular aspects of mouse primordial germ cell migration and proliferation in culture.

$M$ De Felici, S Dolci and M Pesce

Int. J. Dev. Biol. (1992) 36: 205-213

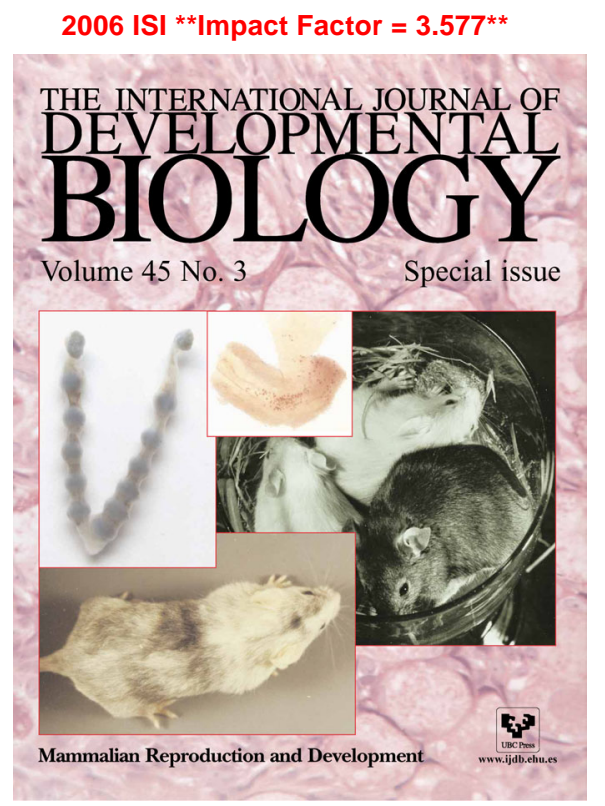

